\title{
Biomolecules from Microalgae and Cyanobacteria: Applications and Market Survey
}

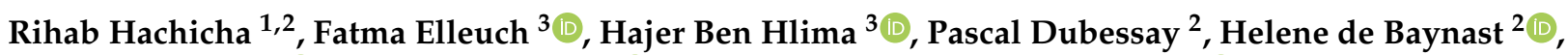

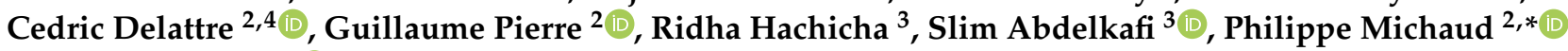 \\ and Imen Fendri ${ }^{2, *} \mathbb{B}$
}

1 Laboratoroire de Biotechnologies Végétales Appliquées à l'Amélioration des Cultures, Faculté des Sciences de Sfax, Université de Sfax, Sfax 3038, Tunisia; hachicharihab63@gmail.com

2 SIGMA Clermont, Institut Pascal, CNRS, Université Clermont Auvergne, 63000 Clermont-Ferrand, France; pascal.dubessay@uca.fr (P.D.); helene.de_baynast@uca.fr (H.d.B.); cedric.delattre@uca.fr (C.D.); guillaume.pierre@uca.fr (G.P.)

3 Laboratoire de Génie Enzymatique et Microbiologie, Equipe de Biotechnologie des Algues, Ecole Nationale d'Ingénieurs de Sfax, Université de Sfax, Sfax 3038, Tunisia; fatma.elleuch@ymail.com (F.E.); hajer_benhlima@yahoo.fr (H.B.H.); ridha.hachicha@yahoo.com (R.H.); slim.abdelkafi@enis.tn (S.A.)

4 Institut Universitaire de France (IUF), 1 Rue Descartes, 75005 Paris, France

* Correspondence: philippe.michaud@uca.fr (P.M.); imen.fendri@fss.usf.tn (I.F.); Tel.: +33-(0)4-7340-7425 (P.M.); +216-95-682-765 (I.F.)

check for updates

Citation: Hachicha, R.; Elleuch, F.; Ben Hlima, H.; Dubessay, P.; de Baynast, H.; Delattre, C.; Pierre, G.; Hachicha, R.; Abdelkafi, S.; Michaud, P.; et al. Biomolecules from Microalgae and Cyanobacteria: Applications and Market Survey. Appl. Sci. 2022, 12, 1924. https:// doi.org/10.3390/app12041924

Academic Editor: Leonel Pereira

Received: 18 December 2021

Accepted: 6 February 2022

Published: 12 February 2022

Publisher's Note: MDPI stays neutral with regard to jurisdictional claims in published maps and institutional affiliations.

Copyright: () 2022 by the authors Licensee MDPI, Basel, Switzerland. This article is an open access article distributed under the terms and conditions of the Creative Commons Attribution (CC BY) license (https:// creativecommons.org/licenses/by/ $4.0 /)$.

\begin{abstract}
Nowadays, microalgae and cyanobacteria have become a promising and sustainable source of useful products, thanks to their richness in bioactive metabolites of high value (antibiotics, toxins, pharmaceutically active compounds, plant growth regulators, and others). These photoautotroph microorganisms generate biomass using photosynthesis. This review, which distinguishes microalgae and Cyanobacteria, often called blue-green microalgae, aims to present their classification and taxonomic diversity as the ecological niches occupied by them. In addition, the usages of open ponds and photobioreactors to produce various microalgae and Cyanobacteria strains and the high-value bioactive compounds from these microorganisms are summarized. Finally, the numerous commercial applications of these phytoplanktons in different fields, such as food, dietary supplements, feed, cosmetic, and biofuel applications, are reviewed.
\end{abstract}

Keywords: microalgae; cyanobacteria; bioactivity; bioconversion

\section{Introduction}

Worldwide population is rising and resulting in an increased demand for food, biofuel, therapeutic molecules, enzymes, pigments, cosmetic products, and others. Given their broad spectrum of applications, the world encourages the production and cultivation of these organisms. At the academic and industrial levels, many researchers are exploring the engineering tools applied to microalgae processes, including techno-economic analysis and integration and intensification processes [1].

Usually, the term algae does not refer to a proper taxonomic group but to an assembly of aquatic organisms that reduce $\mathrm{CO}_{2}$ and produce $\mathrm{O}_{2}$ using photosynthesis, in which chlorophyll a is responsible for $50 \%$ of the photosynthic activity on earth. Organisms from this group vary in size, from micrometers to several tens of meters for some algae [2]. The larger ones, macroalgae, are generally visible to the naked eye and are often known as "seaweeds". The smallest ones, microalgae, are unicellular, microscopic algae that can occur separately or in colonies. Within this group, photosynthetic microorganisms can be divided into eukaryotic cells, including the phyla Chlorophyta, Rhodophyta, Glaucophyta, Cryptophyta, Euglenozoa, Cercozoa, Heterokontophyta, Haptophyta, and Miozoa; the prokaryotic ones are also called blue-green microalgae or Cyanobacteria [3,4]. 
The classification of this diversity is complex, and the taxonomy is subject to frequent upheavals due to the use of molecular phylogeny techniques. Subsequently, some taxonomists contradict classifying Cyanobacteria as microalgae or bacteria [5,6]. Moreover, their evolution was based on the theory of endosymbiosis, according to the characteristics of their mitochondria and plastids [7]. In addition, microalgae and Cyanobacteria are chlorophyll organisms that thrive in water or in very humid environments. Although most abundant in the waters of seas, lakes, and running waters, it is also found on wet rocks and on land. They can live free or fixed to a support structure [8].

Thanks to their different morphological, physiological, and genetic traits, microalgae and Cyanobacteria have the ability to produce various biomolecules and, notably, biologically active metabolites with great potential in a large range of industrial applications [9].

The present work provides a first part that focuses on the richness of microalgal biomass as a basis for the many biotechnological and industrial applications developed in the second part. It also aims to give readers past, present, and future market data.

\section{Microalgae}

\subsection{What Are Microalgae and Cyanobacteria?}

According to phycologists, any organisms containing chlorophyll a (Chl a), devoid of stem, roots, leaves, and flowers, can be considered an alga [10]. These organisms are divided into macro- and microalgae, which are essentially differentiated by their sizes and organelle contents. Macroalgae are benthic, multicellular, and able to reach several meters in length, while microalgae are unicellular microscopic eukaryotic phytoplankton. There is a disagreement among taxonomists in classifying this polyphyletic group of organisms of prokaryotic microalgae, known as Cyanobacteria, as microalgae or bacteria $[5,6]$.

There are obvious distinctions between Cyanobacteria and microalgae-primarily, the presence of membrane-bound structures in eukaryotic cells acquired during evolution through endosymbiosis $[7,11]$. In fact, Cyanobacteria are primitive microorganisms that bear an intermediate structure between bacteria, characterized by the absence of a distinct membrane-bound nucleus, mitochondria, and chloroplasts, and plants by oxygenic photosynthesis. Secondly, eukaryotes are larger, more complex, more diverse, and can be either unicellular or multicellular [12], while prokaryotes are simple and microscopic single-celled organisms that have neither a distinct nucleus with a membrane nor other specialized organelles. Furthermore, Cyanobacteria contain chlorophyll a as a major photosynthetic pigment, which may be accompanied by carotenoids, xanthophylls, and phycobilisomes (mostly phycoerythrin and phycocyanin) as light collectors. It was estimated that around $10^{25}$ cells of these blue-green microorganisms exist in the oceans, where they are responsible for the achievement of the fixation of photosynthetic carbon and nitrogen [13].

Microalgae are able to grow rapidly and live in a wide range of environmental conditions [14]. They are closely guided by abiotic factors (light, salinity, $\mathrm{pH}$, temperature, and trophic limitation or excess) and biotic ones (trophic relationships) [15]. Microalgae generate themselves using photosynthesis by capturing sunlight, $\mathrm{H}_{2} \mathrm{O}, \mathrm{CO}_{2}$, and inorganic nutrients and converting them into biomass, chemical energy, and $\mathrm{O}_{2}$, effectuating a full life cycle every few days [16]. They are more efficient at utilizing sunlight than terrestrial plants (10 times greater), with numerous additional technological advantages such as consuming damaging pollutants, having minimal resource requirements, and not competing with agriculture for precious resources [8].

The presence of microalgae is essential since they represent the basis of several food chains. It is estimated that microalgae and Cyanobacteria are around 200,000 to 800,000. Among them, the sole diatoms are estimated to be over 200,000 [17-19]. Currently, more than 164,800 species and infraspecific names exist in the database Algaebase (https:/ / www. algaebase.org/, accessed on 24 november 2020). This appreciable diversity is associated with richness in lipids, proteins, vitamins, pigments, carbohydrates, and other compounds. 


\subsection{Properties, Taxonomy, and Habitats}

Microscopic in size and giant in their properties, eukaryotic microalgae and Cyanobacteria have a huge assortment of colors and different types of cell organization, e.g., unicellular, colonial, and filamentous. They possess different shapes: spherical (Porphyridium), droplet (Chlamydomonas), filament (Oscillatoria), spiral (Arthrospira/Spirulina), and even star shape (Staurastrum). With a diameter or length of approximately 3 to $10 \mu \mathrm{m}$ and a size ranging from 0.2 to $2 \mu \mathrm{m}$, they could be classified into picophytoplankton $(0.2-2 \mu \mathrm{m})$, nanoplankton $(2-20 \mu \mathrm{m})$, microplankton $(20-200 \mu \mathrm{m})$, and mesoplankton $(200 \mu \mathrm{m}-5 \mathrm{~mm})$ [20].

A microalgal cell contains within its cytoplasm many organelles necessary for sound functioning and metabolism. A single cell may contain one or more chloroplasts. They store their "food" as starch and fats (Table 1). Due to their simple reproduction, their cell growth systems, and their genetic adaptation amenability, they can quickly proliferate by forming phytoplankton "blooms" and survive long term in various harsh environmental conditions (e.g., higher temperature, light intensity, ultraviolet radiations, $\mathrm{CO}_{2}$ levels, and salinity). They can survive short-term environmental stress by physiological acclimatization triggered by modifying their gene expression. Nevertheless, when environmental stress exceeds their physiological limits, adaptation will be acquired through the selection of several mutations with minor effects [21-23].

Table 1. Reserve molecules from photosynthesis products [20].

\begin{tabular}{cc}
\hline Reserve Form & Microalgae \\
\hline Floridian starch (amylopectin subunits) & Red microalgae \\
Myxophyceal starch & Blue-green microalgae \\
(amylopectin or glycogen-like subunits) & Green microalgae \\
Cross-linked amylose-amylopectin starch & Cryptophyceae and Dinoflagellate \\
Fructans (inulin-like fructose oligosaccharides) & Chrysophyceae \\
$\alpha-(1-4)$-glucan & Bacillariophyceae \\
Oil or chrysolaminarin & Euglenophyta and Prymnesiophyceae \\
Paramylon: $\beta-(1-3)$-D-glucan &
\end{tabular}

Diverse groups of microalgae have generated the remarkable wealth production of primary and secondary metabolites. These compounds, sometimes with high added value, are synthesized by several metabolic pathways such as photosynthesis, carotenogenesis, lipogenesis, and glycerol synthesis. Efficient coordination and regulation of the different metabolic pathways have been demonstrated, depending on the conditions and depth of culture in marine and freshwater environments. These autotrophic organisms are responsible for $40 \%$ of photosynthesis on earth [24]. They transform inorganic matter and light energy into chemical energy and different forms of reserve molecules: $\alpha-(1-4)$-Dglucans (such as starches)/ $\beta$-(1-3)-D-glucan, fructans, carbohydrates (such as floridoside) and triacyglycerols [20]. They have three modes of reproduction: sexual by the union of gametes, vegetative by the division of a single cell or by fragmentation of a colony, and, finally, asexual by the production of mobile spores.

Cyanobacteria show enormous biodiversity, and a minority of the described species have been sequenced [25]. They can be either unicellular (Chroococcus) or multicellular (Arthrospira), with coccoid (Chroococcus) or branched filaments (Anabaena), singly or grouped into colonies, nearly colorless or intensely pigmented, autotrophic or heterotrophic, psychrophilic or thermophilic, acidophilic or alkalophilic, planktonic or barophilic, dwelling in fresh water or marine environments, including hypersaline environments (salt pans). They are found both free-living and as endosymbionts [26-28]. They constitute a phylogenetically coherent group of evolutionarily ancient phototrophic Gram-negative bacteria [13] that show a great deal of variety in size, ranging from small forms called picoplankton (less than 2-3 $\mu \mathrm{m}$ ) to larger forms. Cyanobacteria do not contain chloroplast in the cells and keep their energy in reserve in the form of starch or lipids (Table 1). Cyanobacteria are also 
called blue-green algae due to the presence of $\mathrm{Chl}$ a and phycocyanin located in membrane vesicles called thylakoids, which give the cells a bluish color when present in sufficiently high concentrations. Phycoerythrin, a red accessory pigment, can be found as well in these organisms [27].

Cyanobacterial biomass can be estimated at around a thousand million tons $\left(10^{15} \mathrm{~g}\right)$ of wet biomass; therefore, they are considered among the most important organisms on Earth. Discovered as putative microfossils 2000-3500 million years ago, they are also considered among the oldest organisms in evolution and are believed to be ultimately responsible for the oxygenation of Earth's atmosphere during the episode of the "Great Oxidation Event" at the end of the Archean Aeon $[13,28]$. Thought to be amongst the first organisms to colonize the earth, these bacteria are predicted to be the photosynthetic ancestors of chloroplasts in eukaryotes such as plants and algae. In addition, Cyanobacteria have the ability to perform photosynthesis, aerobic respiration, and $\mathrm{CO}_{2}$ and (sometimes) nitrogen fixation. They perform oxygenic photosynthesis like plants and algae, utilizing solar energy and water to generate chemical energy (ATP) and reducing power (NADPH) to fix atmospheric $\mathrm{CO}_{2}$ and synthesize carbohydrates [13,29]. Vermaas (2001) noted that photosynthesis and respiration in Cyanobacteria can take place simultaneously in the same compartment, represented by the thylakoid membrane, thus making this combination a bit unique for them [28]. During photosynthesis, Cyanobacteria use water as an electron donor and produce oxygen as a coproduct. Some filamentous Cyanophycae are characterized by the presence of specialized cells called heterocysts, which allow the fixation of atmospheric $\mathrm{N}_{2}$ in anaeroby and, therefore, give Cyanobacteria the possibility of growth in inorganic nitrogen-depleted environments [30]. In the dark or under anoxic conditions, Cyanobacteria can perform fermentations for energy generation [31]. It may be due to this flexibility of metabolic pathways that these organisms are able to grow under a wide range of conditions.

Unlike eukaryotic organisms, the Cyanobacteria reproduce by vegetative, asexual processes, and sexual reproduction is completely absent. The commonest mode of reproduction among them is undergoing a binary split. Moreover, there have certain specialized structures such as akinetes, hormogonia, hormocysts, and spores, which are partly involved in the process of reproduction [25].

Microalgae and Cyanobacteria are extremely heterogeneous groups gathered around a common characteristic: oxygenic photosynthesis [32]. Among these groups, which exhibit significant taxonomic diversity, the evolution of microalgae was based on the theory of endosymbiosis, according to the characteristics of their mitochondria and plastids [7]. It was proposed that mitochondria originated from the endosymbiosis of $\alpha$-proteobacteria by a protoeukaryote, which thereby developed the complex eukaryote cell. The chloroplast, in turn, takes its origin through the primary endosymbiosis of a Cyanobacterium by this heterotrophic eukaryote, also called "protist". Endosymbiosis may be the origin of the Plantae kingdom, with primary plastids (formed with only two membranes) comprising phyla of Chlorophyta, Glaucophyta, and Rhodophyta. Therefore, photosynthetic membranes of plastids of red algae strongly evoke the thylakoids of photosynthetic bacteria. In addition, the pigment equipment of Rhodophyta ( $\mathrm{Chl} \mathrm{a)}$ and phycobiliproteins resemble that of Cyanobacteria. Other endosymbioses have arisen during the evolution of microalgae, giving rise to organisms with secondary and even tertiary plastids. However, uncertainties relating to the order of appearances and the independence of events still persist. The secondary endosymbiosis took place between a red algae and a non-photosynthetic host cell and gave rise to the ancestor of all Chromalveolata supergroup: Cryptophyta, Haptophyta, Ochrophyta (or Heterokontophyta), and Miozoa. This is the most controversial hypothesis in the literature postulated in 1999 by Cavalier-Smith under the name of "The Chromalveolate Hypothesis" [33]. By a similar process, Euglenophyta, Cercozoa, and green Miozoa acquired their plastids from ancestral Chlorophyta [34-36]. Nevertheless, the work described by Baurain et al. [37] has shown that the differences observed within these groups cannot be fully explained by this hypothesis. For this reason, another theory 
called "The Independent Acquisition Hypothesis" explains the origin of Chromalveolates by a series of endosymbioses.

Therefore, the classification of microalgae is very complex and ambiguous. As mentioned above, it could be based on various different criteria, such as the organization of photosynthetic membranes, but also other criteria such as the chemical nature of storage products and, most commonly, their pigmentation [38,39]. In addition to the morphological basis, Reviers Bruno de [40] and Groendahl et al. [41] have proposed a classification of microalgae and Cyanobacteria by means of molecular biology techniques based on the sequence alignments of genes encoding the $16 \mathrm{~S}$ and 23SrRNAs for Cyanobacteria and $18 \mathrm{~S}$ and $28 \mathrm{SrRNAs}$ for microalgae in order to establish family ties between these microorganisms. Other methods, such as the flow cytometer, ensuring semi-automated or fully automated classification, have been recently employed to identify and classify algal species [42]. Currently, there is no specific classification used by the taxonomists since the taxonomic organization may change over the years [43,44].

As early as their discovery, different kinds of classification of algae were proposed. For example, [5,45,46] classified microalgae and Cyanobacteria into 11 and 10 classes, respectively. Contrary to the classification of Fritsh, where the 11th class consists of Cyanobacteria, Chapman employed the Procaryota-Eucaryota concept in the classification of microalgae. Table 2 summarizes this classification by implementing the main characteristics of the different classes. Table 3 presents the classification of microalgae and Cyanobacteria, detailing their branches. Those tables show that microalgae and Cyanobacteria are a mixture of different kingdoms: Eubacteria, Protozoa, Chromists, and Plants. This classification is based on data from Ruggiero et al., published in 2015 [47], who detailed the distribution of all living organisms.

Table 2. Classification of microalgae and Cyanobacteria $[20,45,46]$.

\begin{tabular}{|c|c|c|c|c|c|c|c|}
\hline Phylum & Class & Pigments & Reserve & Flagellation & Reproduction & Cell Envelope & Habitat \\
\hline Cyanobacteria & Cyanophyceae & $\begin{array}{c}\text { Chl a, } \\
\beta \text {-carotene, } \\
\text { flavacene, } \\
\text { Echinenone } \\
\text { isozea-, zea-, } \\
\text { myxo-, } \\
\text { oscillaxanthin } \\
\text { APC, C-PC, C-PE }\end{array}$ & $\begin{array}{l}\text { Starch (granule) } \\
\text { and glycogen }\end{array}$ & Unflagellated & $\begin{array}{l}\text { Simple division, } \\
\text { non-motile } \\
\text { endospore, } \\
\text { vegetative } \\
\text { fragmentation } \\
\text { No sexual } \\
\text { reproduction }\end{array}$ & Lack of cellulose & $\begin{array}{c}\text { Marine } \\
\text { Freshwater } \\
\text { Terrestrial }\end{array}$ \\
\hline Chlorophyta & $\begin{array}{l}\text { Chlorophyceae } \\
\text { Trebouxiophyceae } \\
\text { Ulvophyceae }\end{array}$ & $\begin{array}{l}\text { Chl a, b, } \alpha \text { and } \\
\beta \text {-carotene, } \\
\text { lutein, } \\
\text { zea-, viola-, loro- } \\
\text { and neoxanthin }\end{array}$ & $\begin{array}{l}\text { Starch } \\
\text { Oil }\end{array}$ & $\begin{array}{l}\text { From two to four } \\
\text { flagella (mobile), } \\
\text { isokont }\end{array}$ & $\begin{array}{c}\text { Isogamy, } \\
\text { anisogamy, } \\
\text { oogamy } \\
\text { Motile zoospore, } \\
\text { non-motile spore }\end{array}$ & $\begin{array}{c}\text { Cellulose+ } \\
\text { mannans+ } \\
\text { xylans } \\
\text { Sitosterol } \\
\text { Sometimes } \\
\text { calcified }\end{array}$ & $\begin{array}{l}\text { Marine } \\
\text { Freshwater }\end{array}$ \\
\hline Euglenophyta & Euglenophyceae & $\begin{array}{l}\text { Some colorless } \\
\text { Chl a, b, } \\
\text { diadinoxanthin }\end{array}$ & $\begin{array}{l}\text { Paramylon } \\
\text { Ergosterol }\end{array}$ & $\begin{array}{l}\text { One or two } \\
\text { flagella, one of } \\
\text { which contains } \\
\text { cilia and the } \\
\text { second being } \\
\text { reduced }\end{array}$ & $\begin{array}{l}\text { Longitudinal } \\
\text { division }\end{array}$ & $\begin{array}{c}\text { No cell } \\
\text { membrane } \\
\text { Flexible periplast } \\
\text { or pellicle }\end{array}$ & $\begin{array}{c}\text { Marine } \\
\text { Freshwater } \\
\text { Terrestrial }\end{array}$ \\
\hline $\begin{array}{l}\text { Heterokontophyta/ } \\
\text { Ochrophyta }\end{array}$ & $\begin{array}{l}\text { Xanthophyceae } \\
\text { Eustigmatophyceae }\end{array}$ & $\begin{array}{c}\text { Chl a and c, } \\
\beta \text {-carotene, } \\
\text { heteroxanthin, } \\
\text { diadinoxanthin } \\
\quad(++)\end{array}$ & $\begin{array}{c}\text { Oil } \\
\text { Leucosin } \\
\text { Ergosterol }\end{array}$ & $\begin{array}{l}\text { Two heterokont } \\
\text { flagella and } \\
\text { sometimes a } \\
\text { single flagellum }\end{array}$ & $\begin{array}{l}\text { Zoospore, } \\
\text { aplanospores, } \\
\text { statospores } \\
\text { Isogamy, } \\
\text { oogamy } \\
\text { (Vaucheria) }\end{array}$ & $\begin{array}{l}\text { Rich in pectic } \\
\text { compounds } \\
\text { Silicification } \\
\text { during the rest } \\
\text { period }\end{array}$ & $\begin{array}{l}\text { Marine } \\
\text { Freshwater } \\
\text { Terrestrial }\end{array}$ \\
\hline Miozoa & Dinophyceae & $\begin{array}{c}\text { Chl a, c, } \\
\beta \text {-carotene, } \\
\text { diadinoxanthin, } \\
\text { dinoxanthin, } \\
\text { peridinins }\end{array}$ & $\begin{array}{l}\text { Starch } \\
\text { Lipids }\end{array}$ & Lateral biflagella & $\begin{array}{c}\text { Zoospore } \\
\text { Longitudinal } \\
\text { oblique division } \\
\text { Aniso or } \\
\text { isogamy }\end{array}$ & $\begin{array}{l}\text { With or without } \\
\text { cellulose }\end{array}$ & $\begin{array}{c}\text { Marine } \\
\text { Freshwater }\end{array}$ \\
\hline $\begin{array}{l}\text { Heterokontophyta/ } \\
\text { Ochrophyta }\end{array}$ & Chrysophycea & $\begin{array}{c}\text { Chl a, c, } \beta \text {-carot, } \\
\text { Fuco-, Diato-, } \\
\text { diadinoxanthin }\end{array}$ & $\begin{array}{c}\text { Chrysolaminarin } \\
\text { Fucosterol } \\
\text { Porifasterol }\end{array}$ & $\begin{array}{l}\text { Two heterokont } \\
\text { flagella }\end{array}$ & $\begin{array}{l}\text { Zoospore, } \\
\text { statospore }\end{array}$ & $\begin{array}{l}\text { Less cellulose } \\
\text { with silicification } \\
\text { or calcification of } \\
\text { the membrane }\end{array}$ & $\begin{array}{c}\text { Marine } \\
\text { Freshwater }\end{array}$ \\
\hline
\end{tabular}


Table 2. Cont.

\begin{tabular}{|c|c|c|c|c|c|c|c|}
\hline Phylum & Class & Pigments & Reserve & Flagellation & Reproduction & Cell Envelope & Habitat \\
\hline Haptophyta & $\begin{array}{l}\text { Coccolithophyceae } \\
\text { Pavlovophyceae } \\
\text { Rappephyceae }\end{array}$ & $\begin{array}{c}\text { Chl a, c, } \beta \text {-carot, } \\
\text { Fuco-, Diato-, } \\
\text { diadinoxanthin }\end{array}$ & $\begin{array}{c}\text { Chrysolaminarin } \\
\text { Fucosterol } \\
\text { Porifasterol }\end{array}$ & $\begin{array}{c}\text { Two isokont } \\
\text { flagella }+ \\
\text { haptonema }\end{array}$ & $\begin{array}{l}\text { Zoospore, } \\
\text { statospore }\end{array}$ & $\begin{array}{l}\text { Less cellulose } \\
\text { with silicification } \\
\text { or calcification of } \\
\text { the membrane }\end{array}$ & $\begin{array}{l}\text { Marine } \\
\text { Freshwater }\end{array}$ \\
\hline $\begin{array}{l}\text { Bacillariophyta } \\
\text { (Diatoms) }\end{array}$ & Bacillariophyceae & $\begin{array}{c}\text { Chl a, c, } \beta \text {-carot, } \\
\text { Fuco-, Diato-, } \\
\text { diadinoxanthin }\end{array}$ & $\begin{array}{l}\text { Chrysolaminarin } \\
\text { Oil }\end{array}$ & $\begin{array}{c}\text { Without } \\
\text { flagellum except } \\
\text { for male gametes }\end{array}$ & $\begin{array}{l}\text { Cell division } \\
\text { Oogamie } \\
\text { (centered } \\
\text { diatoms) } \\
\text { Amoeboid } \\
\text { isogamy } \\
\text { (pinnate } \\
\text { diatoms) }\end{array}$ & $\begin{array}{l}\text { Silica + pectic } \\
\text { compounds }\end{array}$ & $\begin{array}{c}\text { Marine } \\
\text { Freshwater } \\
\text { Terrestrial }\end{array}$ \\
\hline Cryptophyta & Cryptophyceae & $\begin{array}{c}\text { Chl a, c, } \\
\text { Biliproteins, } \\
\alpha \text {-carot, Allo-, } \\
\text { Croco-, } \\
\text { Monado-xanthin }\end{array}$ & $\begin{array}{c}\text { Starch (granule) } \\
\text { Oil } \\
\text { Carbohydrates }\end{array}$ & $\begin{array}{c}\text { Two unequal } \\
\text { flagella except } \\
\text { for Bjornbergiella } \\
\text { and } \\
\text { Tetragonidium }\end{array}$ & Zoospores & $\begin{array}{l}\text { Proteinaceous } \\
\text { periplast }\end{array}$ & $\begin{array}{l}\text { Marine } \\
\text { Freshwater }\end{array}$ \\
\hline $\begin{array}{l}\text { Heterokontophyta/ } \\
\text { Ochrophyta }\end{array}$ & Phaeophyceae & $\begin{array}{l}\text { Chl a, c, } \beta \text {-carot, } \\
\text { violaxanthin } \\
\text { Fucoxanthin }(++)\end{array}$ & $\begin{array}{l}\text { Mannitol } \\
\text { Laminarin } \\
\text { Lipids }\end{array}$ & $\begin{array}{l}\text { Two heterokont } \\
\text { flagella }\end{array}$ & $\begin{array}{c}\text { Monospores, } \\
\text { tetraspores, } \\
\text { non-motile } \\
\text { aplanospores } \\
\text { From isogamy to } \\
\text { oogamy }\end{array}$ & $\begin{array}{l}\text { Cellulose + } \\
\text { alginic acid + } \\
\text { fucoidin }\end{array}$ & $\begin{array}{c}\text { Marine } \\
\text { Freshwater } \\
\text { Terrestrial }\end{array}$ \\
\hline Rhodophyta & $\begin{array}{l}\text { Porphyridiophyceae } \\
\text { Bangiophyceae } \\
\text { Florideophyceae }\end{array}$ & $\begin{array}{c}\text { APC, C-PC, } \\
\text { R-PC, B-PE, } \\
\text { R-PE, } \\
\text { phytochrome, } \alpha \\
\text { and } \beta \text { carot, Chl } \\
\text { a and d, } \\
\text { zeaxanthin, } \\
\text { lutein }\end{array}$ & $\begin{array}{c}\text { Starch, } \\
\text { floridoside, } \\
\text { mannoglycerate, } \\
\text { sulfated } \\
\text { polysaccharides }\end{array}$ & No flagella & $\begin{array}{l}\text { Oogamy } \\
\text { complex }\end{array}$ & $\begin{array}{l}\text { Carbohydrates } \\
\text { (xylose, cellulose, } \\
\text { galactane) }\end{array}$ & $\begin{array}{c}\text { Marine } \\
\text { Freshwater } \\
\text { Terrestrial }\end{array}$ \\
\hline
\end{tabular}

Table 3. Classification of microalgae and Cyanobacteria according to their phyla (based on data from Ruggiero et al. [47] and https:/ / www.algaebase.org/, accessed on 24 November 2020).

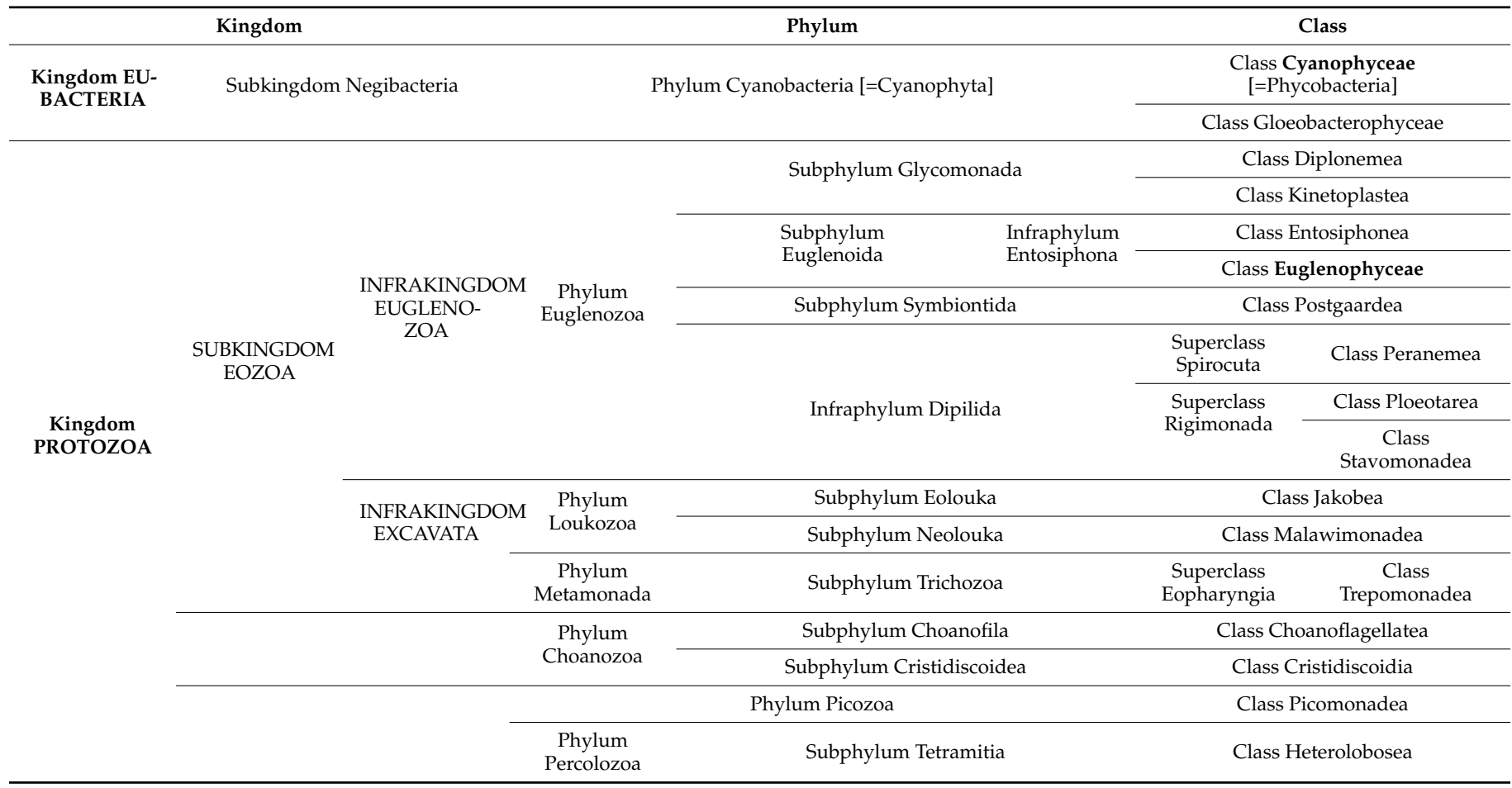


Table 3. Cont.

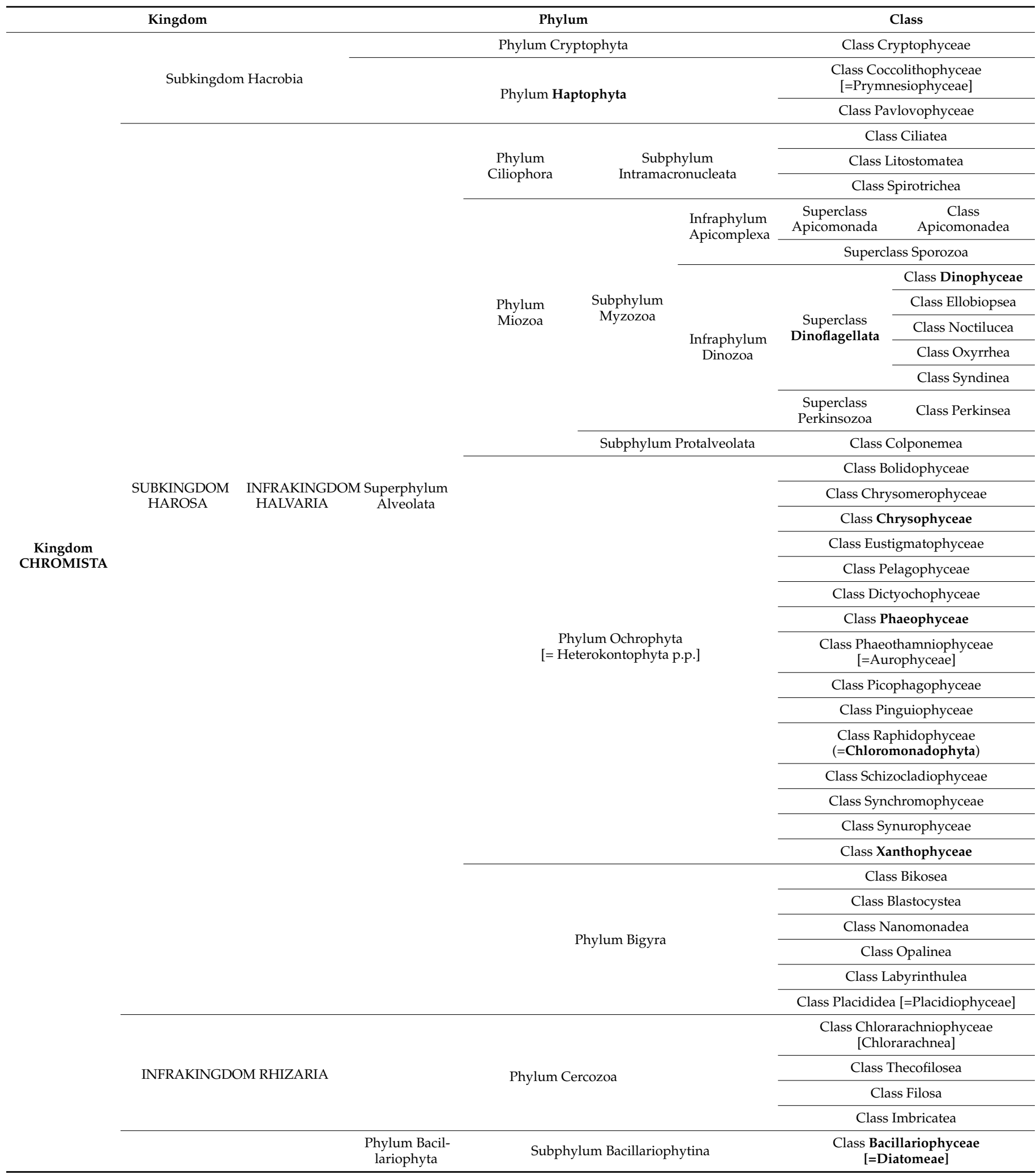


Table 3. Cont.

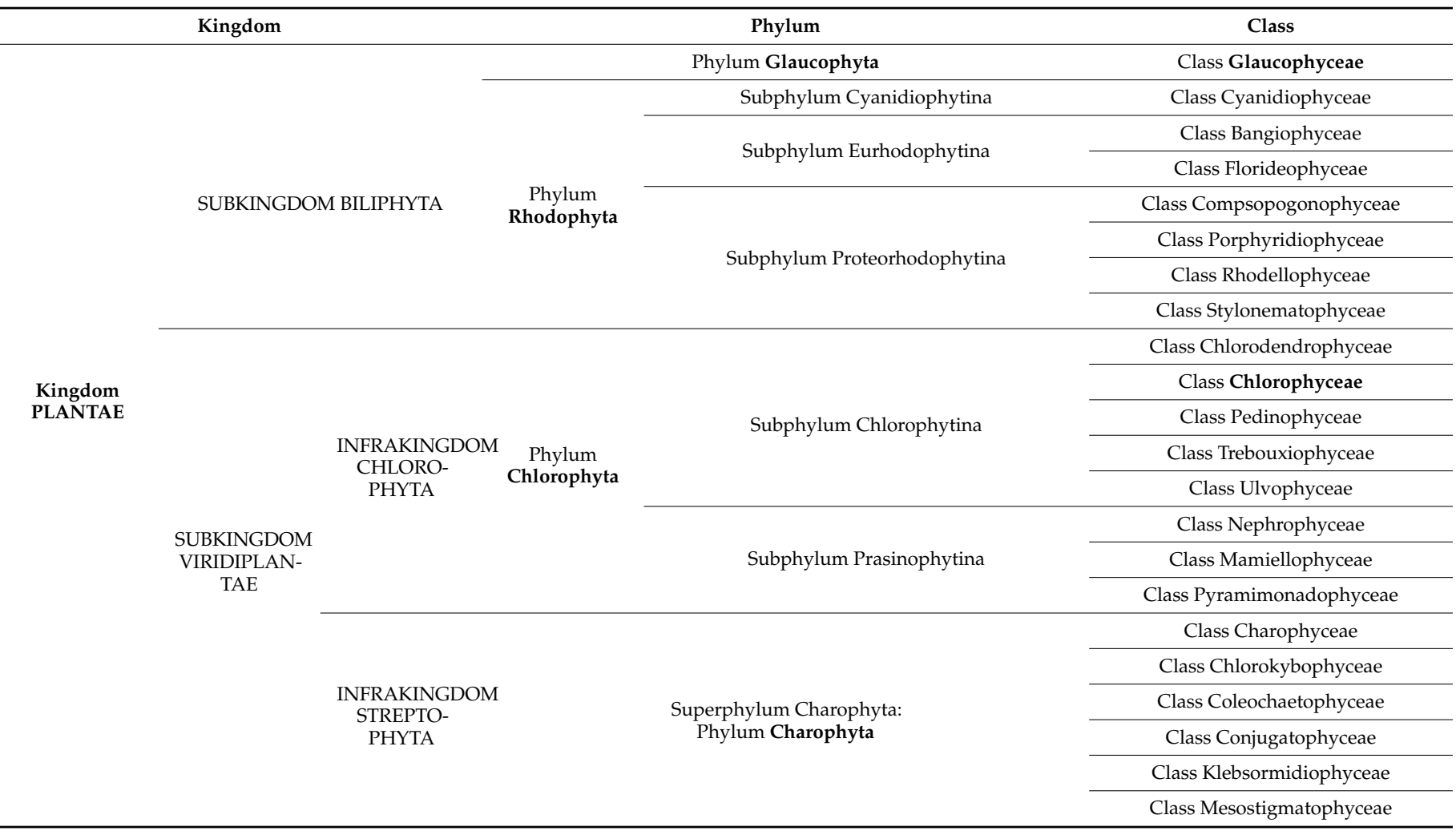

Microalgae and Cyanobacteria are ubiquitous, and they occupy various types of ecological niches. Most of them thrive in fresh, saline, or brackish waters. Some of them are also capable of forming a sticky coating in the form of "biofouling" biofilms on various terrestrial habitats such as soil and rocks, tree trunks, or even architectural buildings $[8,48]$ (Table 2). There are many parameters that influence the habitat of the microalgae and Cyanobacteria, mainly the salinity and the availability of substrates. The temperature and the quantity and quality of light are also among the principal factors influencing their habitat. At sea level, these two factors depend on the movement of the tides and the seacoast depth. Indeed, algae spread according to the sea depth, influencing the availability of the wavelengths that can be absorbed by their pigments. Some authors define this mechanism by the chromatic adaptation in algae [49]. The latter can be considered as a change in the absorption spectrum of an organism, activated by different spectral compositions and intensities of incident solar energy [50]. Green microalgae are present on the surface, adapted to red wavelengths. Brown microalgae are found between green and red microalgae, which are found in the deeper strata. In this depth, they exploit the green and blue wavelengths. However, this parameter does not prevent us from sometimes finding green microalgae living in deeper depths and red microalgae on the surface. This diversity of color allows microalgae to easily absorb the dominant rays in the solar radiation at various depths [51].

\subsection{Compositions and Technologies for Photoautotrophic Production of Microalgae and Cyanobacteria}

Different morphological, physiological, and genetic traits confer on microalgae the ability to produce different biologically active metabolites. This implies biochemical diversity, which becomes the basis for many biotechnological and industrial applications. In fact, microalgae biomass contains important primary metabolites such as lipids, proteins, and carbohydrates, with food and nutraceutical applications. Nevertheless, bioactive compounds also can be synthesized from secondary metabolism with cosmetics and phar- 
maceutical aims [24,52]. Similarly, Cyanobacteria from marine and freshwater sources are known to produce a variety of bioactive compounds (secondary metabolites) that are derived from mixed biosynthetic pathways endowed with diverse biological activities, including antiviral, antibacterial, antifungal, antimalarial, antitumoral, and antiinflammatory properties [53-55].

\subsubsection{Amino acids, Peptides, and Proteins}

Microalgae and Cyanobacteria are considered to be rich and natural sources of vegetable proteins, mainly used as functional ingredients [56]. Indeed, they can produce proteins from $6 \%$ to $80 \%$ of their dry mass, depending on the species [57], e.g., Chlorella vulgaris (Chlorophyta) (51-58\% DW), Arthrospira maxima (Cyanobacteria) (60-71\% DW), Isochrysis galbana (Haptophyta) (50-56\% DW), or Porphyridium purpureum (Rhodophyta) (28-39\% DW). Moreover, bioactive peptides are convenient high added-value compounds for humans due to their therapeutic potential in the treatment of various diseases, in addition to providing nutritional benefits [56].

Besides their high protein content, microalgae and Cyanobacteria are also known for their high amino acid (Aas) content, in which the more abundant are aspartate and glutamate [39]. According to Sousa et al. [58], microalgae contain essential amino acids compared to egg and soybean. Microalgae and Cyanobacteria, such as those belonging to the species Nostoc sphaeroides, Arthrospira platensis (Cyanobacteria), and Chlorella vulgaris (Chlorophyta), show a large variability in protein digestibility, with values of $82 \%, 81 \%$, and 76\%, respectively [59]. Aminograms of Arthrospira extracts with high protein digestibility (83-90\%) have highlighted all essential amino acids, particularly, leucine, valine, and isoleucine [60]. The increased digestibility of Cyanobacteria is explained by their thinner cell wall. Kose et al. [61] reported that other species, such as Nannochloropsis oceanica (Eustigmatophyceae) and Chlorella sorokiniana (Chlorophyta), may exhibit low digestibility rates of $50 \%$ and $55 \%$, respectively, due to the rigidity and thickness of their cell walls, which are considered digestibility barriers.

Cyanobacteria represent an inexhaustible source of proteins and various compounds with promising antiviral activities. Cyanovirin- $\mathrm{N}$ is an $11 \mathrm{KDa}$ protein produced by Nostoc ellipsosporum that displays viricidal activity against several viruses and, notably, the human immunodeficiency virus (HIV). Other microbial metabolites were equally reported to exhibit antiviral activities, such as Scytovirin, a single 95-amino acids protein, which was isolated from the Cyanobacteria Scytonema varium, with potent antiviral activity against HIV.

\subsubsection{Photosynthetic Pigments}

Photosynthetic pigments of microalgae and Cyanobacteria are composed of chlorophylls, carotenoids, and phycobiliproteins (phycoerythrin, phycocyanin, and allophycocyanin). These three groups confer on microalgae their green, yellow/orange, and red/blue colors, respectively [62]. Natural pigments derived from microalgae and Cyanobacteria are of great importance for the food, cosmetic, and pharmaceutical industries. They are not only responsible for capturing solar energy for photosynthesis but also play a role in photoprotective processes and display antioxidant, anticarcinogen, anti-inflammatory, antiobesity, antiangiogenic, and neuroprotective activities [24,63]. Chlorophylls, which represent $0.5 \%$ to $1.5 \%$ of dry matter of microalgae and Cyanobacteria, are green, lipid-soluble pigments that play a major role in photosynthesis. They are tetra-pyrrolic macrocycles that are metalized by the presence of a complexed magnesium atom in their center and substituted by a phytyl chain, and they may be found in algae, higher plants, and Cyanobacteria.

Chlorophyll a (Chl a) is present in all algae and has a major peak of light absorption at $683 \pm 20 \mathrm{~nm}$ due to the activity of photosystem II (PSII) and a second one at 700 to $750 \mathrm{~nm}$ due to both PSII and PSI [64]. This photosynthetic pigment is accompanied by accessory ones, including chlorophylls b, cl, c2 and d, phycobiliproteins, and carotenoids, which absorb at different wavelengths, thus expanding the spectrum of light-harvesting [20]. 
Chlorophyll b, c, and $\mathrm{d}$ are variants of the $\mathrm{Chl}$ a found in green algae, brown algae, and Rhodophyta, respectively [65].

Present as orange, red, or yellow colors, carotenoids ( $0.1 \%$ to $0.2 \%$ of dry matter) are responsible not only for the primary coloration of some algal groups but also for the mechanism of photosynthesis [66]. Carotenoids are chemically subdivided into deoxygenated carotenes, principally $\beta$-carotene, which is the most widely known of the carotenoids because of its antioxidant property as well as its dyeing power. Known as provitamin A (precursor of vitamin A), $\beta$-carotene is mainly produced by the hypersaline species Dunaliella salina (Chlorophyta), which can accumulate up to $98.5 \%$ of this compound in relation to its total carotenoids and about $13 \%$ of its dry biomass [39]. The second major group is the red oxygenated pigment. The freshwater chlorophyceae Haematococcus lacustris (Chlorophyta) is considered the primary source of astaxanthin as it was found to have the highest production on the industrial scale and can accumulate up to $81 \%$ of astaxanthin of its total carotenoids and about 7\% of its dry weight [67-69]. This pigment is commercially produced from Chlorella zofingiensis, Chlorococcum sp., and Scenedesmus $\mathrm{sp}$. Astaxanthinis is described in the literature as having a higher antioxidant activity, health benefits, and dyeing power compared with those of $\alpha$ - and $\beta$-carotenes, lutein and lycopene, canthaxanthin, and tocopherols $[24,39,70]$. Phycobiliproteins are colored (blue or red pigments) and water-soluble pigments organized in supramolecular complexes, called phycobilisomes, mainly present in Cyanophyta, Rhodophyta, Glaucophyta, and Cryptophyta. These complexes consist of $85 \%$ phycobiliproteins, of which 4 classes can be distinguished: allophycocyanin at the center of the complex, phycocyanin, followed by phycoerythrin or phycoerythrocyanin at the level of the radiary projections. The characteristics of these pigments have been detailed by Thomas (1989) [71]. They absorb light in the visible region of 450-650 $\mathrm{nm}$. They are used as natural colorants in the food, cosmetic, and pharmaceutical industries as substitutes for synthetic dyes. The species most commonly used for the production of phycobiliproteins are Porphyridium sp. (Rhodophyta), Arthrospira/Spirulina sp., and Aphanizomenon flosaquae (Cyanobacteria) [39,70].

\subsubsection{Lipids and Fatty Acids}

Lipids from microalgae and Cyanobacteria are classified into two categories, which are: (i) storage lipids, mainly triglycerides that are non-polar lipids produced by photosynthesis and stored in cells and (ii) structural lipids, such as phospholipids and sterols, which are plastid and cell membrane polar lipids [72]. Microalgae are able to accumulate up to $20-50 \%$ of their dry weight in lipids, and this content can reach $80 \%$ in response to changes in nutritional and environmental conditions (nitrogen concentration, salinity, or temperature). Furthermore, microalgae contain very rich and diverse fatty acid profiles. The latter are the primary metabolites with 14-20 carbons, belonging to the class of storage lipids mainly used for applications focusing on the production of biodiesel. Saturated and polyunsaturated (PUFAs) fatty acids with more than 20 carbon atoms are used in food as health food supplements and in the pharmaceutical industry for docosahexaenoic (DHA) and eicosapentaenoic (EPA) acids. In addition, the lipid composition of microalgae is very rich in essential PUFAs such as $\omega 3$, in particular eicosapentaenoic ( $\omega 3$, EPA, C20: 5) and docosahexaenoic ( $\omega 3$, DHA, C22: 6) and $\omega-6$ fatty acids. The fatty acid composition of microalgae and Cyanobacteria depends essentially on the species. The Chlorella species are known for their high content of DHA and EPA (3.24\% and $8.9 \%$ of total fatty acid methyl esters (FAMEs), respectively, in addition to saturated fatty acids). The fatty acids extracted from Chlorella vulgaris are mainly composed of oleic, palmitic, and linolenic acids. The green algae Haematococcus are characterized by its short-chain fatty acids profile with antimicrobial activity, while the Cyanobacterium Arthrospira/Spirulina represents a good source of $\gamma$-linolenic acid, sterols, and fatty acids such as palmitic, lauric, oleic acids, and DHA. Diatoms are considered to be a promising source of EPA ( $15 \%$ to $30 \%$ of total fatty acids) but not DHA, contrary to dinoflagellates, which have a high potential for use in the commercial production of this compound, which ranges from $12 \%$ to $51 \%$ of 
total fatty acids [39,72-74]. Different antimicrobial, antiviral, anticancer, and antiprotozoal compounds have been reported from Cyanobacteria. Singh et al. [75,76] mentioned that lipopeptides from Cyanobacteria have cytotoxic (41\%), antitumor (13\%), antiviral (4\%), antibiotic (12\%) activities, and the remaining $18 \%$ include antimalarial and antimycoticsone activities. Some Cyanobacteria also have the potential to produce intracellular and extracellular bioactive compounds with potent antibacterial and antifungal activities against many fungi and Gram-positive and Gram-negative bacteria. However, some of the antimicrobial compounds isolated from Cyanobacteria exhibit cytotoxicity and may be ineffective for use in pharmaceuticals [77].

Cyanobacteria are a source of value-added products such as isoprene, which is an unsaturated, energy-rich hydrocarbon widely used as a biofuel by the chemical industry. Polyhydroxyalkanoates are biodegradable and biocompatible polyesters produced in nature by numerous Cyanobacteria, including Aphanothece sp., Oscillatoria limosa, Arthrospira/Spirulina, and the thermophilic strain Synechococcus sp. MA19. This polymer has gained immense attention for industrial applications, such as replacements for conventional non-biodegradable plastics, as well as in the biomedical or pharmaceutical field [78]. Additionally, Cyanobacteria produce a broad spectrum of compounds with anticancer activity. These compounds show potential benefits against cancer, including cell cycle arrest by inhibition of cell growth using apoptotic processes and mitochondrial dysfunctions. For example, some compound extracts from the genus Arthrospira/Spirulina resulted in the inhibition of homogenous leukoplakia. Others repressed chemically induced carcinogenesis in model hamster buccal pouches [76].

\subsubsection{Carbohydrates}

Microalgae have been suggested as a promising source of carbohydrates, which are located not only inside the chloroplast but also in the cytosol and extracellular compartments. These mono-, oligo-, and polysaccharides are produced during photosynthesis, and their contents can reach $50 \%$ of the dry weight of some microalgae, depending on the species and the cultivation and environmental conditions $[39,78]$. Cyanobacteria and red microalgae store, respectively, glycogen $(\alpha-(1,4-1,6)-\mathrm{D}-$ glucan) and floridean starch (hybrid between starch and glycogen), while green microalgae accumulate amylopectin-like polysaccharides $[39,78]$ (Table 3 ).

Carbohydrates are classified as simple or complex compounds. The former contains just one or two sugars and are called monosaccharides, while the latter has two or more sugars, called di-, oligo-, and polysaccharides. The latter are polymers of carbohydrates (glycans), and they are extracted from many species and genera of microalgae, mainly from Chlorella sp., Tetraselmis sp. (Chlorophyta), Isochrysis sp. (Haptophyta), Porphyridium purpureum, and Dixoniella grisea (Rhodophyta) [65,78,79]. Some microalgae also produce, depending on species, structural polysaccharides qualified as fibrillary, which participate in the formation of the cell wall and could be used in pharmaceutical, cosmetic, and food industries. They also have the potential of applications such as thickening or gelling agents as well as bioactive compounds, citing antiviral, anti-inflammatory, anticoagulant and antithrombotic, antitumor, and immunomodulatory activities [80]. The second class is known as energy reserve polysaccharides and exocellular polysaccharides (EPSs), mainly used for biofuel production. Finally, polysaccharides can also be involved in cell communication [40]. Carbohydrates such as Nostoflan, cyclic depsipeptides, microvirin, ichthyopeptins A and $\mathrm{B}$, and many others compound extracts from Cyanobacteria also show strong antiviral properties $[13,76,77]$.

\subsubsection{Other Compounds}

Microalgae have also been recognized as an excellent source of vitamins and minerals, some of them having antioxidant properties such as the hydrosoluble vitamins $(\mathrm{C}, \mathrm{B} 1, \mathrm{~B} 2$, B3, B5, B6, B9, and B12) and fat-soluble ones (provitamin A and vitamins E, D, and K). They also contain nicotinate, biotin, folic acid, and pantothenic acid as well as macrominerals 
( $\mathrm{Na}, \mathrm{K}, \mathrm{Ca}$, and $\mathrm{Mg}$ ) and microminerals $(\mathrm{Fe}, \mathrm{Zn}, \mathrm{Mn}$, and $\mathrm{Cu}$ ) [81-84]. Parts of prokaryotic microalgae are known for their large-scale production of vitamins of commercial interest, such as vitamins B and E, and Spirulina is part of this. In fact, this Cyanobacterium is known to be a rich source of vitamin B12, $\beta$-carotene, thiamin, and riboflavin [77].

Microalgal biomass also contains an abundance of a wide variety of secondary bioactive substances. Within this bioactive diversity, phenolic compounds constitute one of the most numerous and abundant groups of phytochemicals, which exhibit a wide range of biological properties, such as antioxidant, anti-inflammatory, anticancer, antiallergic, antidiabetes, antiaging, and antimicrobial properties [39]. Moreover, microalgae and Cyanobacteria have great potential for synthesizing enzymes such as cellulases, galactosidases, amylases, proteases, lipases, phytases, laccases, phosphatases, and antioxidant enzymes, with high potential for several applications [77,84]. Microalgae also produce phytohormones such as auxin, abscisic acid, cytokinin, ethylene, gibberellins, polyamines, and jasmonides, mainly known to regulate the main physiological processes of plants, terrestrial or aquatic organisms [79,85,86], phytosterols [39], and others.

\subsubsection{Technologies for Photoautotrophic Production of Microalgae and} Cyanobacterial Biomass

Given the great interests of algae and their broad spectrum of applications, the world is invited to push and encourage the production and cultivation of these organisms. Furthermore, until 2011, global algal exploitation remained marginal, with 15 million tons/year of macroalgae and 4 billion tons/year of terrestrial plants against 10,000 tons/year of microalgae [38]. New estimates show that between 2016 and 2018, the production of microalgae, including Cyanobacteria, bounded by 19,000 and 20,000 tons per year. By 2024, their expected commercial production will be 27,500 tons per year, with a market value of USD 1.1 billion [87]. The challenge nowadays will be to improve current cultivation methods to scale up this production. Macroalgae are cultivated in a natural marine environment, while microalgae and Cyanobacteria are cultivated in reactors, either in photoautotrophy (raceways or photobioreactors) or in heterotrophy [38]. These two production systems remain, in fact, the most practical, as mentioned next.

Open ponds are the most exploited processes for the industrial culture of microalgae and Cyanobacteria due to their ease of use and low cost. These systems generally use natural light and vary according to their shape, the type of materials used, as well as the mixing system. They are mainly classified into two types: circular and "raceway" ponds [88]. The first open ponds, qualified as natural basins, were without agitation and generally had low cell productivity. In order to overcome this problem, mixing systems with a circular shape and centrally pivoted rotating agitator were then put in place for the production of biomass, animal feed (aquaculture), and dietary supplements based on Arthrospira/Spirulina (Cyanobacteria) or Chlorella (Chlorophyta) [89]. Open raceway tanks later appeared, characterized by an elongated shape, and they are currently the most widely used artificial systems for microalgal cultivation. This design consists of a closed-loop flow channel with a typical culture depth of approximately 12 to $50 \mathrm{~cm}$, in which the mixing and circulation of the microalgae culture are promoted by paddle wheels [90]. Light intensity is considered among the parameters that strongly influence the growth rates of microalgae in outdoor cultures. Moreover, with such a mixing system, microalgae have better access to sunlight, which can come only from the top. Besides light, dissolved $\mathrm{CO}_{2}$ concentration is another important parameter for productivity in these systems. Indeed, atmospheric $\mathrm{CO}_{2}$ uptake by microalgae and Cyanobacteria is not sufficient for optimal growth. In open reactors, supplementary to light and $\mathrm{CO}_{2}$ availabilities, factors such as temperature and the mixing and availability of nutrients are involved in reaching optimal growth and are strongly affected by the culture depth [90].

Photobioreactors (PBRs) are closed systems that consist either of horizontally or vertically arranged tubes or vertically arranged panels, wherein microalgae or Cyanobacteria are grown. This technology offers better control of all culture parameters such as $\mathrm{pH}$, 
temperature, oxygen, and agitation. They are well suited for microalgae sensitive to contamination, such as extremophilic microalgae. Depending on location and metabolite production, they may or may not be artificially illuminated. During the last decades, the marketing of industrial PBRs with different designs and efficiencies has increased the yields of biomass production. Several shapes are currently available, such as sleeves, tubular reactors, annular reactors, flat reactors, rigid panel type reactors, and "airlift" type reactors (bubble column) [88,91].

Microalgae and Cyanobacteria can be harvested by mechanical, chemical, biological, and electrical methods. They are based on the principles of separation by the density difference or cells sizes. For the first strategy, we cite sedimentation, flocculation-settling, flotation, and centrifugation techniques, while the second one is based on membrane processes such as micro- or ultrafiltration [38]. The choice of the used technique depends on the chosen microalgae morphology, specifications of the final product, the ability to reuse the culture medium, as well as the density and size of the microalgal cell [92]. Likewise, to improve harvesting efficiencies, the process should not only be effective for the majority of microalgae and allow for a higher biomass concentration but should also require moderate costs of operation energy and maintenance. Therefore, the harvesting process cost is also very important as it usually accounts for about $20-30 \%$ of the total microalgal production cost. Thus, it is better to apply a combination of reliable and lowcost processes such as coagulation/flocculation by mechanical, chemical, and biological methods, which are the most used to reduce operation and maintenance charges. Filtration, centrifugation-, and electrical-based processes remain the least used due to their high energy and equipment costs.

\section{Current Uses of Microalgae and Cyanobacteria in Industry}

Thanks to their important and diverse high-added-value contents, industrial microalgae and Cyanobacteria production has increased in these last years. By 2050, the world population will exceed 9 billion, which will compel humanity to find and use new sources for food. In fact, 70\% more food will be needed, according to Food and Agriculture Organization (FAO) organization (www.fao.org, accessed on 10 November 2020). In addition to this increase, demand for food and fuel production will be affected by climate change and the decline of ordinary resources. Microalgae and Cyanobacteria could represent a natural alternative for the resolution of these problems. The National Center for Biotechnology Information expects that, by 2050, algae could provide $18 \%$ of protein sources (www.fortunebusinessinsights.com, accessed on 7 December 2020). Currently, algae production is rising as their compound annual growth rate (CAGR) will increase by $4.3 \%$ in the period 2020-2027, according to www.strategyr.com, accessed on 11 November 2020). It was estimated that in 2020, dyeing agents are at the head of the list of microalgae products on the market, with USD 800 million, followed by pharmaceuticals/chemicals (USD 500 million), nutraceuticals (USD 300 million), and, finally, cosmetics (USD 30 million) [39].

\subsection{Microalgae and Cyanobacteria as Food, Dietary Supplements, and Feed}

Microalgae and Cyanobacteria provide to the consumer an unrepeatable source of high-value compounds. Therefore, they are mostly commercialized as health products, diet supplements, functional food, and nutraceuticals in capsules, tablets, powders, pills, and syrups forms [93]. Table 4 presents different industries producing food supplements and nutraceuticals from microalgae and Cyanobacteria. Chlorella (Chlorophyta) and Arthrospira/Spirulina (Cyanobacteria) are the most popular genus used as diet supplements. They constitute $80 \%$ of the global microalgae food market, thanks to their composition (www.fortunebusinessinsights.com, accessed on 14 February 2021). 
Table 4. Uses of microalgae and Cyanobacteria for food supplement and nutraceutical production by some industries.

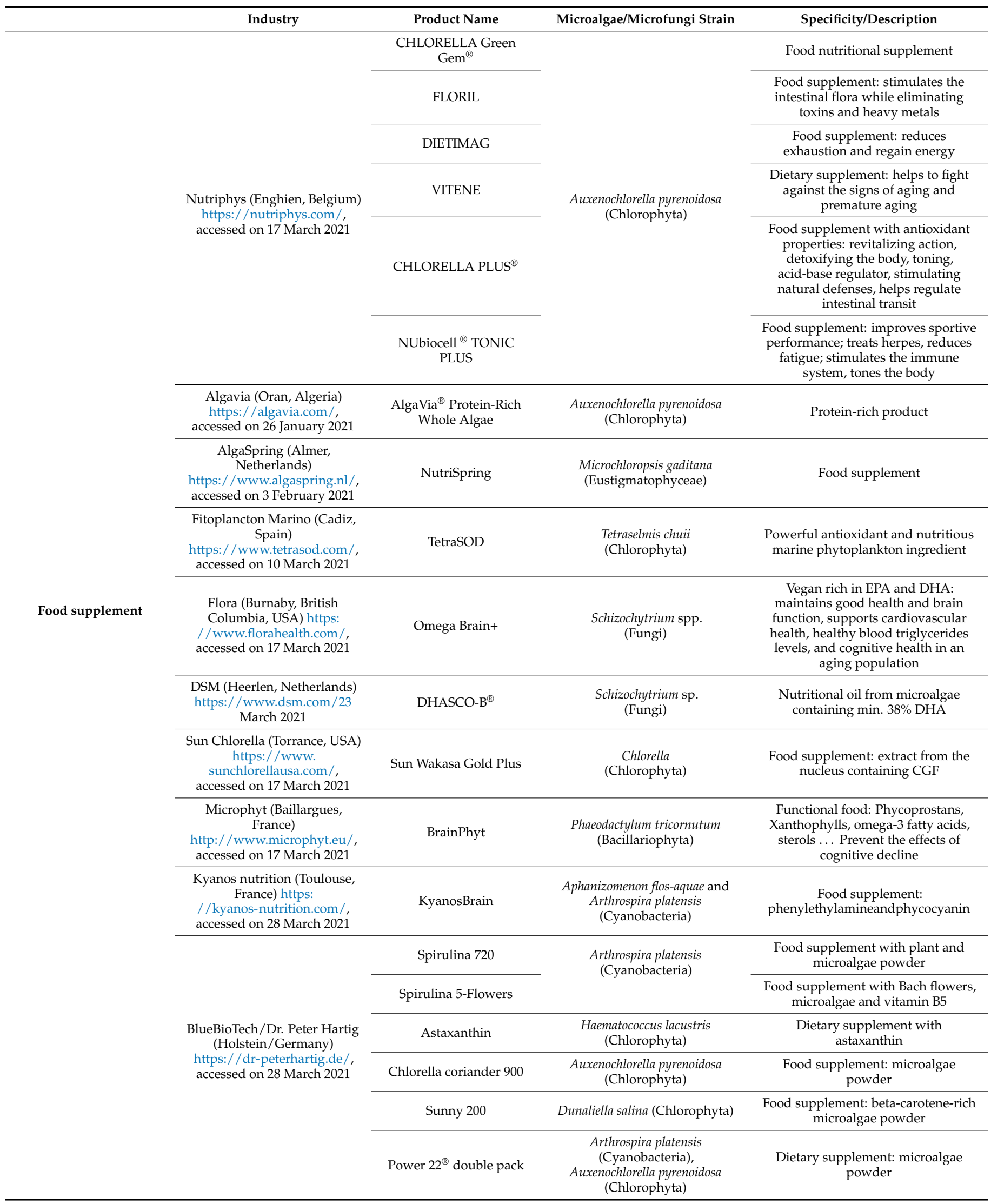


Table 4. Cont.

\begin{tabular}{|c|c|c|c|c|}
\hline & Industry & Product Name & Microalgae/Microfungi Strain & Specificity/Description \\
\hline \multirow{9}{*}{ Nutraceuticals } & \multirow{2}{*}{$\begin{array}{l}\text { AlgaTechnologies Ltd. (Hevel } \\
\text { Eliot, Israel) } \\
\text { https: / / www.algatech.com/, } \\
\text { accessed on } 29 \text { March } 2021\end{array}$} & FucoVital $^{\mathrm{TM}}$ & $\begin{array}{c}\text { Phaeodactylum tricornutum } \\
\text { (Bacillariophyta) }\end{array}$ & Fucoxanthin \\
\hline & & AstaPure & $\begin{array}{c}\text { Haematococcus } \\
\text { lacustris(Chlorophyta) }\end{array}$ & Astaxanthin \\
\hline & $\begin{array}{l}\text { Fuji Chemical Industries } \\
\text { (Toyama, Japan) http: } \\
\text { / / www.fujichemical.co.jp/, } \\
\text { accessed on 29 March 2021 }\end{array}$ & AstaReal & $\begin{array}{l}\text { Haematococcus lacustris } \\
\text { (Chlorophyta) }\end{array}$ & Astaxanthin \\
\hline & $\begin{array}{l}\text { Cyanotech (Kailua-Kona, } \\
\text { Hawai) https: } \\
\text { / / www.cyanotech.com/, } \\
\text { accessed on } 17 \text { March } 2021\end{array}$ & BioAstin & $\begin{array}{l}\text { Haematococcus lacustris } \\
\text { (Chlorophyta) }\end{array}$ & Astaxanthin \\
\hline & $\begin{array}{c}\text { Progress Biotech (Capelle aan } \\
\text { den IJssel, Netherlands) } \\
\text { https:/ / www. } \\
\text { progressbiotech.com/, } \\
\text { accessed on } 6 \text { March 2021 }\end{array}$ & DHA algal oil & $\begin{array}{l}\text { Schizochytrium } \\
\text { (Fungi) }\end{array}$ & DHA (omega-3) \\
\hline & $\begin{array}{c}\text { Parry nutraceuticals } \\
\text { (Onnaiyur, India) } \\
\text { https://www. } \\
\text { parrynutraceuticals.com/, } \\
\text { accessed on 6 January 2021 }\end{array}$ & Organicphycocyanin & $\begin{array}{l}\text { Arthrospira/Spirulina } \\
\text { (Cyanobacteria) }\end{array}$ & Phycocyanin \\
\hline & $\begin{array}{l}\text { Kyanos nutrition (Toulouse, } \\
\text { France) https: } \\
\text { // kyanos-nutrition.com/, } \\
\text { accessed on } 12 \text { March } 2021\end{array}$ & Kyanos Blue & $\begin{array}{l}\text { Arthrospira/Spirulina } \\
\text { (Cyanobacteria) }\end{array}$ & Phycocyanin \\
\hline & $\begin{array}{c}\text { BASF (Ludwigshafen, } \\
\text { Germany) } \\
\text { https:/ / nutrition.basf.com/, } \\
\text { accessed on 2 February 2021 }\end{array}$ & Betatene & Dunaliella salina (Chlorophyta) & $\beta$-carotene \\
\hline & $\begin{array}{c}\text { Algosource (Saint Nazaire, } \\
\text { France) } \\
\text { https:/ / algosource.com/, } \\
\text { accessed on } 12 \text { March } 2021\end{array}$ & Spirulysat & $\begin{array}{l}\text { Arthrospira/Spirulina } \\
\text { (Cyanobacteria) }\end{array}$ & $\begin{array}{l}\text { Extract of phycocyanin with } \\
\text { polysaccharides, amino acids }\end{array}$ \\
\hline
\end{tabular}

Spirulina is known as an interesting source of proteins, phycobiliproteins, vitamin B12, minerals, $\gamma$-linolenic acid, and others. Its production and consumption are in continuous growth. In a previous assessment, the global production of dried Spirulina was 12,000 tons.year $^{-1}$. In 2014, FAO estimated a Spirulina global production of 86,000 tons [94]. According to persistence market research, over 128,000 tons of Spirulina were globally consumed in 2016 (www.persistencemarketresearch.com/, accessed on 14 February 2021). Its global market size was USD 348 million in 2018 and is projected to reach USD 779 million by 2026, growing at a CAGR of 10.5\% from 2019 to 2026 (www.alliedmarketresearch.com, accessed on 14 February 2021). In their report, Persistence Market Research affirmed that the powder form of Spirulina was the highest form used as, in 2016, this segment represented $73.5 \%$, and it is expected that its consumption will record a CAGR of $10.2 \%$ in the period 2019-2026. In second place, the demand for tablets and capsules will increase to a CAGR of $8.8 \%$ in the same period. By 2026, more than 250,000 tons of Spirulina will be consumed globally in the production of nutraceuticals (www.persistencemarketresearch.com/, accessed on 14 February 2021). The aqueous extract of this blue-green microalgae, rich in natural phycocyanin colorant, was authorized by the Food and Drug Administration (FDA) at a maximum level of $2 \mathrm{mg} \cdot \mathrm{kg}^{-1}$ to be safely used in coloring confections and in dietary supplement tablets and capsules (www.accessdata.fda.gov, accessed on 10 December 2020). Different companies are currently producing phycobiliprotein around the world, such as Parry Nutraceuticals (Pudukkottai District, Unaiyur, Tamil Nadu, India), Kyanos nutrition (Toulouse, France), and Greensea (Mèze, France), which produce C-PC, R-PC, APC, R-PE, and B-PE. Algosource Technology (Saint Nazaire, France) is developing different extracts from Arthrospira platensis (Cyanobacteria), which are Spirulysat, an aqueous extract rich in phycocyanin and Spirugrass, a fraction from the biorefining of Spirulina, rich in amino acids, iron, vitamin K, and beta-carotenes. Spirulina diet supplements are advantageous 
for athletes, women during pregnancy and lactation, malnourished children, and even for cosmonauts in long space travels.

Chlorella is also considered an exceptional source of proteins, especially in its hot water extract, known as Chlorella growth factor (CGF), rich in amino acids, vitamins, peptides, minerals, and nucleic acids (DNA and RNA). It was demonstrated to promote growth and healing, stimulate the immune system, and control body weight and serum lipid content [95]. Chlorella production has doubled, as it was 2000 tons.year $^{-1}$ in 2003 [96], to be over 5000 tons.year $^{-1}$ [39]. The largest Chlorella producers are situated in Taiwan. Its commercial market value is around one billion US dollars [94].

The global algae protein market will exceed USD 1 billion by 2026; algae protein capsules demand, mainly by sports athletes, will increase by over $6 \%$ by the same year. In 2018, dietary supplements represented about $42 \%$ of the global algae protein market, simultaneously with the expansion of the nutraceuticals industry in China, Japan, and India. Other microalgae or their extracts, such as Dunaliella, Haematococcus, Scenedesmus (Chlorophyta), Aphanizomenon (Cyanobacteria), Odontella (Bacillariophyta), Porphyridium (Rhodophyta), Schizochytrium, and Ulkenia (Marine Fungi), have been accepted in food and health-food markets [93]. Between 2017 and 2019, three microalgae/microfungi (Euglena gracilis-Euglenozoa, Tetraselmis chui-Chlorophyta, and Aurantiochytrium limacinumFungi) were recommended for full Qualified Presumption of Safety status, according by the European Food Safety Authority [97]. Table 5 presents examples of the authorized microalgae and Cyanobacteria and their respective allowed levels for specified foods given by the union list of novel foods in accordance with Regulation European Union (EU) 2015/2283 of the European Parliament and of the Council on novel foods (https: // eur-lex.europa.eu/legal-content/, accessed on 27 November 2020) and also by the FDA [98]. Schizochytrium sp. oil, extracted in specified conditions, was authorized as a novel food by the EFSA [99]. Many companies are producing this oil, rich in DHA, such as DSM (Heerlen, The Netherlands), Progress Biotech (Capelle aan den Ijssel, Netherlands), Bioplus Life Sciences PvT (Bengaluru, Karataka, India), Mara Renewables Corporation (Dartmouth, NH, Canada), and BASF (Ludwigshafen, Germany) (Table 4). It was proposed as an alternative to fish DHA.

Carotenoid production is also in perpetual growth, with a CAGR estimated at $4.2 \%$. Its annual market size is projected to grow from USD 1.5 billion in 2019 to USD 2 billion in 2026 (www.marketsandmarkets.com/, accessed on 26 January 2021). This rise goes together with scientific acceptance and authorization. Betatene, produced by BASF, is an extract of $\beta$ carotene from Dunaliella salina used as dietary supplements as well as functional foods and beverages. Dunaliella production also increased from 1200 tons.year $^{-1}$ to 3000 tons.year $^{-1}$. The D. salina global market is estimated to reach a CAGR of $5.1 \%$ and will evolve from USD 472.3 million in the year 2020 to US D 671 million by 2027 (www.researchandmarkets.com, accessed on 26 January 2021). The EFSA has accepted the use of an AST-rich oleoresin from Haematococcus lacustris (Chlorophyta) algae as a food supplement up to $40-80 \mathrm{mg} \cdot \mathrm{day}^{-1}$ (Table 5) [100]. AST was shown to be a powerful dietary antioxidant. There are also many companies producing AST, such as Fuji Chemical Industries Co., Ltd. (Toyama, Japan), Cyanotech (Kailua-Kona, Hawai, HI, USA), Algalif (Reykjanesbaer, Iceland), and Microphyt (Baillargues, France). Its global market is expected to reach USD 770 million by 2024, where the global nutraceuticals industry will be assessed to have consumed $54.8 \%$ of $\mathrm{H}$. lacustris microalgae natural AST in 2017 to reach 190 metric tons by 2024 (www.businesswire.com, accessed on 14 February 2021). The H. lacustris market is estimated to grow at a CAGR of 13.2\% from 2020 to 2027 to reach USD 148.1 million by 2027 (www.globenewswire.com, accessed on 14 February 2021). 
Table 5. Microalgae and Cyanobacteria authorized for incorporation into food products according to the European Union ("EUR-Lex-02017R2470-20200827-EN-EUR-Lex," n.d.) and the Food and Drug Administration (Nutrition, 2020).

\begin{tabular}{|c|c|c|c|c|}
\hline $\begin{array}{l}\text { Microalgae/ } \\
\text { Microfungi }\end{array}$ & Fraction & Specified Food Category & Maximum Dose & Authorized by \\
\hline \multirow{3}{*}{$\begin{array}{l}\text { Ulkenia sp. } \\
\text { (Marine Fungi) }\end{array}$} & \multirow{3}{*}{ Extracted oil } & $\begin{array}{c}\text { Bakery products } \\
\text { (breads, rolls, and sweet cookies) }\end{array}$ & $200 \mathrm{mg} \cdot 100 \mathrm{~g}^{-1}$ & \multirow{21}{*}{ EU } \\
\hline & & Cereal bars & $500 \mathrm{mg} \cdot 100 \mathrm{~g}^{-1}$ & \\
\hline & & $\begin{array}{l}\text { Non-alcoholic drinks } \\
\text { (including milk drinks) }\end{array}$ & $60 \mathrm{mg} \cdot 100 \mathrm{~mL}^{-1}$ & \\
\hline $\begin{array}{l}\text { Haematococcus lacustris } \\
\text { (Chlorophyta) }\end{array}$ & $\begin{array}{l}\text { extracted Oleoresin rich in } \\
\text { astaxanthin }\end{array}$ & Food supplements & $\begin{array}{l}40-80 \mathrm{mg} \text { oleoresin per } \\
\text { day, equivalent to } \leq 8 \mathrm{mg} \\
\text { astaxanthin per day }\end{array}$ & \\
\hline \multirow{6}{*}{$\begin{array}{l}\text { Odontella aurita } \\
\text { (Bacillariophyta) }\end{array}$} & & Flavored pasta & $1.5 \%$ & \\
\hline & & Fish soups & $1 \%$ & \\
\hline & & Marine terrines & $0.5 \%$ & \\
\hline & & Court bouillon preparations & $1 \%$ & \\
\hline & & Crackers & $1.5 \%$ & \\
\hline & & Frozen breaded fish & $1.5 \%$ & \\
\hline \multirow{7}{*}{$\begin{array}{l}\text { Schizochytrium sp. } \\
\text { (Marine Fungi) }\end{array}$} & \multirow{7}{*}{$\begin{array}{l}\text { Extracted oil with high } \\
\text { DHA and EPA content }\end{array}$} & $\begin{array}{l}\text { Food supplements, intended for } \\
\text { the adult population, excluding } \\
\text { pregnant or breastfeeding } \\
\text { women }\end{array}$ & $3000 \mathrm{mg} \cdot \mathrm{day}^{-1}$ & \\
\hline & & $\begin{array}{c}\text { Food supplements, intended for } \\
\text { pregnant or breastfeeding } \\
\text { women }\end{array}$ & $450 \mathrm{mg} \cdot$ day $^{-1}$ & \\
\hline & & $\begin{array}{l}\text { Substitutes for the total daily } \\
\text { ration for weight control }\end{array}$ & $250 \mathrm{mg}$ & \\
\hline & & $\begin{array}{l}\text { Milk-based beverages and } \\
\text { similar products intended for } \\
\text { young children }\end{array}$ & \multirow{3}{*}{$200 \mathrm{mg} \cdot 100 \mathrm{~g}^{-1}$} & \\
\hline & & $\begin{array}{l}\text { Cereal-based preparations and } \\
\text { baby food intended for infants } \\
\text { and young children }\end{array}$ & & \\
\hline & & $\begin{array}{l}\text { Foods suitable for intense } \\
\text { muscular expenditure (for } \\
\text { athletes) }\end{array}$ & & \\
\hline & & $\begin{array}{c}\text { Dairy product substitutes, except } \\
\text { beverages }\end{array}$ & $\begin{array}{l}600 \mathrm{mg} \cdot 100 \mathrm{~g}^{-1} \mathrm{for} \\
\text { cheeses; } 200 \mathrm{mg} \cdot 100 \mathrm{~g}^{-1} \\
\text { for soy milk and imitation } \\
\text { milk products (except } \\
\text { beverages) }\end{array}$ & \\
\hline \multirow{4}{*}{$\begin{array}{l}\text { Tetraselmis chuii } \\
\text { (Chlorophyta) }\end{array}$} & \multirow{4}{*}{ Dried microalgae } & Sauces & $20 \%$ or $250 \mathrm{mg} \cdot$ day $^{-1}$ & \\
\hline & & Special salts & $1 \%$ & \\
\hline & & Condiments & $250 \mathrm{mg} \cdot \mathrm{day}^{-1}$ & \\
\hline & & Food supplements & $250 \mathrm{mg} \cdot \mathrm{day}^{-1}$ & \\
\hline $\begin{array}{l}\text { Arthrospira/Spirulina } \\
\text { (Cyanobacteria) }\end{array}$ & Extract (color additive) & $\begin{array}{l}\text { Coloring confections, frostings, } \\
\text { ice cream and frozen desserts, } \\
\text { dessert coatings and toppings, } \\
\text { beverage mixes and powders, } \\
\text { yogurts, ... }\end{array}$ & & FDA \\
\hline $\begin{array}{l}\text { Haematococcus sp. } \\
\text { (Chlorophyta) }\end{array}$ & Meal & Salmonid fish feed only & $\begin{array}{l}\text { Total astaxanthin from all } \\
\text { astaxanthin color additive } \\
\text { sources } \leq 80 \mathrm{mg} \text { per } \mathrm{kg} \text { of } \\
\text { finished feed }\end{array}$ & FDA \\
\hline
\end{tabular}


The introduction of microalgae as food ingredients and the demand for high-addedvalue products are increasing despite some concerns of the algae powder consistence, color, fishy smell, and production cost [101]. Some companies have incorporated Chlorella in noodles (Sun Chlorella (Torrance, CA, USA), Paldo (Seoul, Korea)), bars and cookies (Allma (Lisboa, Portugal)), and in mayonnaise to replace eggs (Fooding Company (Sucy-en-Brie, France)) (Table 6).

Table 6. Microalgae exploitation in food and feed domains.

\begin{tabular}{|c|c|c|c|c|}
\hline & Industry & Product Name & Microalgae Strain & Description \\
\hline \multirow{8}{*}{ Food } & \multirow{3}{*}{$\begin{array}{l}\text { Allma (Pataias, Portugal) } \\
\text { https://www.allmicroalgae.com/en/, } \\
\text { accessed on } 26 \text { January } 2021\end{array}$} & $\begin{array}{c}\text { Bars with } \\
\text { microalgae-Chlorella }\end{array}$ & \multirow{3}{*}{$\begin{array}{c}\text { Chlorella } \\
\text { (Chlorophyta) }\end{array}$} & Bars \\
\hline & & Chlorella Cookies & & Cookies \\
\hline & & $\begin{array}{l}\text { Seeds Crunchy Bar. Bar with } \\
\text { microalgae }\end{array}$ & & Seeds Crunchy Bar \\
\hline & $\begin{array}{l}\text { Sun Chlorella (Torrance, USA) } \\
\text { https:// www.sunchlorellausa.com/, } \\
\text { accessed on } 17 \text { March } 2021\end{array}$ & Chlorella Udon Noodles & Chlorella (Chlorophyta) & Noodles \\
\hline & $\begin{array}{l}\text { Paldo (Seoul, South Korea) } \\
\text { http://www.paldofood.com/, } \\
\text { accessed on } 18 \text { March } 2021\end{array}$ & Green Tea Chlorella Noodles & Chlorella (Chlorophyta) & Noodles \\
\hline & $\begin{array}{c}\text { Fooding Company (Sucy-en-Brie, } \\
\text { France) http:/ / foodingcompany.com/, } \\
\text { accessed on } 18 \text { March } 2021\end{array}$ & The good spoon & Chlorella (Chlorophyta) & Mayonnaise \\
\hline & $\begin{array}{c}\text { eChlorial (L'isle-d'Abeau, France) } \\
\text { https://www.echlorial.fr/, accessed } \\
\text { on } 19 \text { March } 2021\end{array}$ & TetraselmischuiieChlorial & $\begin{array}{l}\text { Tetraselmis chuii } \\
\text { (Chloroophyta) }\end{array}$ & Sea spice, condiment \\
\hline & $\begin{array}{l}\text { The Algae Factory (Wageningen, The } \\
\text { Netherlands) http://thealgaefactory. } \\
\text { com/the-milk-chocolate/, accessed on } \\
17 \text { March } 2021\end{array}$ & The dark chocolate & $\begin{array}{l}\text { Arthrospira/Spirulina } \\
\text { (Cynaophya) }\end{array}$ & Chocolate \\
\hline \multirow{3}{*}{ Feed } & $\begin{array}{l}\text { AlgaSpring (E. Heimansweg Almere, } \\
\text { The Netherlands) https://www. } \\
\text { algaspring.nl/nannochloropsis- } \\
\text { gaditana-micro-algae/, accessed on } 17 \\
\text { March 2021 }\end{array}$ & NannoStar & $\begin{array}{l}\text { Microchloropsis gaditana } \\
\text { (Chlorophyta) }\end{array}$ & Aquaculture feed \\
\hline & $\begin{array}{c}\text { TomAlgae (Belgium) } \\
\text { https:/ / www.tomalgae.com/, } \\
\text { accessed on } 19 \text { March } 2021\end{array}$ & TomAlgae (ThalaPure) & freeze-dried algae & Aquaculture feed \\
\hline & $\begin{array}{c}\text { Solazyme (San Francisco, USA) } \\
\text { https: / / algaprime.com/, accessed on } \\
17 \text { March } 2021\end{array}$ & AlgaPrime $^{\mathrm{TM}} \mathrm{DHA}$ & Microalgae & $\begin{array}{l}\text { Companion animals and in } \\
\text { aquaculture feed }\end{array}$ \\
\hline
\end{tabular}

Microalgae constitute equally an important feed for animals, especially with the expansion of aquaculture, the reduction of land fertility, and scientific evidence on their positive effect on animal health. For example, carotenoids have been incorporated as a pigment in egg yolks, broiler skin, fishes, and crustaceans. Microalgae feeds are largely used in aquaculture and poultry as a source of DHA and proteins. Nannostar, based on the microalgae Microchloropsis gaditana (Eustigmatophyceae), is produced by AlgaSpring (Almere, The Netherlands) for aquaculture purposes. It is rich in EPA (20:5 omega-3) and other fatty acids such as C14:0, C16:0, C16:1, C18:1, and C18:2. It contains $\beta$-carotene, violaxanthin, tocopherols, various sterols, and valuable minerals. Some industries use a combination of microalgae, as in the case of Easybooster (Fitoplancton marino, Cádiz, Spain), commercialized as a liquid phytoplankton extract combining 33\% of Isochrysis (T-ISO), 31\% of Nannochloropsis, 18\% of Tetraselmis, and 18\% Phaeodactylum (Table 6).

Microalgae are an important food for some marine bivalve mollusks, the larval stages of abalone and conch gastropods, the larvae of several marine fish species, penaeid shrimp, and zooplankton [102]. For adult fish, the use of microalgae is limited as fishmeal is still cheaper [101]. Oostlander estimated the cost of live microalgae production for feed in aquaculture hatcheries as 300-600 EUR $\cdot \mathrm{kg}^{-1}$ biomass. This cost could be reduced using larger-scale production [103]. 


\subsection{Use of Microalgae and Cyanobacteria for Cosmetic Applications}

Microalgae and Cyanobacteria have been incorporated into face, skin, and hair care products, in addition to sun protection compounds such as antioxidants, thickening, and water-binding agents [104]. Some industries in this field develop their own microalgae culture, but others tend to develop collaborations with industries producing microalgae, such as Rejuvasea ${ }^{\circledR}$ (NV, USA), which commercializes products containing active compounds from marine microalgae provided by Fitoplancton Marino (Cadiz, Spain). Some brands incorporate in their products extracts from more than one microalga in combination with other plant extracts, as Estee Lauder (New York, NY, USA) and Algenist, which is Solazyme's skincare line. The latter produces a whole range of cosmetic products based on microalgae (Table 7). In the literature, several works have been carried out to evaluate the effect of these extracts by in vitro and in vivo studies. Rumin et al. [105] reported that in 2015 and 2017, the number of publications was about 25 per year, where France, Spain, and Germany were the top publishers. They focus mainly on the antioxidant and antiinflammatory activities of microalgae extracts and the potential of bioactive compounds in the treatment of skin problems such as aging, tanning, and pigment disorders [106]. For instance, the effect of Dermochlorella D, produced by CODIF, an aqueous extract of Chlorella vulgaris rich in amino acids, was COSMOS approved. This label is managed by a not-for-profit, international, and independent association, and it represents a consumer guarantee for organic and natural cosmetics. The effect of this extract was studied by in vitro test on fibroblasts and keratinocytes. It was shown that the mentioned extract ameliorated the skin structure by an increase in collagen- $1,-3$, and -4 and also laminin- 6 and elastin expressions by human fibroblasts, as well as collagen-7, laminin-5, and elafin expressions by keratinocytes. It also improved skin protection against free radicals by increasing the expression of thioredoxin-1 and thioredoxin-2, which could reduce skin process aging. Furthermore, it protects Langerhans cells against ultraviolet exposure [106]. Phormiskin from CODIF Company took the second prize at the "BSB Innovation Awards 2010 " for the most innovative ingredient focused on natural products.

Table 7. Microalgae and Cyanobacteria exploitation in the cosmetic field.

\begin{tabular}{|c|c|c|c|c|}
\hline Industry & Product & Microalgae & Fraction Used & Effect \\
\hline \multirow{3}{*}{$\begin{array}{c}\text { DSM } \\
\text { (Heerlen, The Netherlands) } \\
\text { https://www.dsm.com/, accessed } \\
\text { on 26 January 2021 }\end{array}$} & PEPHA $^{\circledR}$-CTIVE & $\begin{array}{l}\text { Dunaliella salina } \\
\text { (Chloroophyta) }\end{array}$ & $\begin{array}{l}\text { aqueous extract rich in amino } \\
\text { acids, minerals, and } \\
\text { carbohydrates }\end{array}$ & $\begin{array}{l}\text { Skin care: reloads skin with } \\
\text { new energy and improves its } \\
\text { radiance. }\end{array}$ \\
\hline & PEPHA $^{\circledR}$-TIGHT & $\begin{array}{l}\text { Microchloropsis gaditana } \\
\text { (Chlorophyta) }\end{array}$ & $\begin{array}{c}\text { aqueous extract rich in } \\
\text { vitamin } C \text {, vitamin } B 12 \text {, and } \\
\text { polysaccharides }\end{array}$ & $\begin{array}{c}\text { Skin care: Tightening effect } \\
\text { and long-term skin firming } \\
\text { effect }\end{array}$ \\
\hline & PEPHA-AGE & $\begin{array}{l}\text { Halochlorella rubescens } \\
\text { (Chlorophyta) }\end{array}$ & $\begin{array}{l}\text { aqueous extract rich in amino } \\
\text { acids, vitamins (B3), algal } \\
\text { saccharides, and minerals } \\
\text { (Zn) }\end{array}$ & $\begin{array}{l}\text { Skin protection from blue } \\
\text { light and UV }\end{array}$ \\
\hline $\begin{array}{l}\text { Evonik (Frankfurt, Germany) } \\
\text { https: / / corporate.evonik.com/en, } \\
\text { accessed on } 26 \text { January } 2021\end{array}$ & TEGO $^{\circledR}$ Stemlastin & $\begin{array}{l}\text { Cyanidium caldarium } \\
\text { (Rhodophyta) }\end{array}$ & n.d. & $\begin{array}{l}\text { Skin care: retains a youthful } \\
\text { skin appearance and reduces } \\
\text { the signs of chronological } \\
\text { skin aging }\end{array}$ \\
\hline
\end{tabular}


Table 7. Cont.

\begin{tabular}{|c|c|c|c|c|}
\hline Industry & Product & Microalgae & Fraction Used & Effect \\
\hline \multirow{5}{*}{$\begin{array}{l}\text { CODIF technologie naturelle } \\
\text { (SaintMalo, France) } \\
\text { http:// www.codif-tn.com/, } \\
\text { accessed on } 12 \text { January } 2021\end{array}$} & Phormiskinbioprotech $\mathrm{g}$ & $\begin{array}{l}\text { Pseudanabaena persicina } \\
\text { (Cyanobacteria) }\end{array}$ & Concentrate microalgae & $\begin{array}{l}\text { Skin care: against } \\
\text { photo-aging of the skin, } \\
\text { makes skin pigmentation } \\
\text { uniform and adds luster to } \\
\text { the skin tone }\end{array}$ \\
\hline & Detoxondria & $\begin{array}{c}\text { Rhodella } \\
\text { (Rhodophyta) }\end{array}$ & Concentrate microalgae & $\begin{array}{l}\text { Skin care: improves tissue } \\
\text { oxygenation and luminosity } \\
\text { of the skin, reduces the } \\
\text { susceptibility of the skin to } \\
\text { fatigue and signs of fatigue }\end{array}$ \\
\hline & Rosacea & $\begin{array}{l}\text { Rhodella violacea } \\
\text { (Rhodophyta) }\end{array}$ & The complete extract & Skin care: hydrates the skin \\
\hline & Dermochlorella D & $\begin{array}{l}\text { Chlorella vulgaris } \\
\text { (Chlorophyta) }\end{array}$ & $\begin{array}{l}\text { aqueous extract rich in amino } \\
\text { acid concentrate }\end{array}$ & $\begin{array}{l}\text { Skin care: reactivates collagen } \\
\text { synthesis }\end{array}$ \\
\hline & Goldella & $\begin{array}{l}\text { Chlorella vulgaris } \\
\text { (Chlorophyta) }\end{array}$ & Extracted oil rich in lutein & Skin care: Anti-Aging \\
\hline \multirow{2}{*}{$\begin{array}{l}\text { Sun Chlorella (Torrance, USA) } \\
\text { https: } \\
\text { / / www.sunchlorellausa.com/, } \\
\text { accessed on 26 January } 2021\end{array}$} & $\begin{array}{c}\text { Astarella Primetime Skin } \\
\text { Cream }\end{array}$ & Chlorella (Chlorophyta) & Astaxanthin and CGF & $\begin{array}{l}\text { Skin care: ensures } \\
\text { healthy-looking skin }\end{array}$ \\
\hline & Sun Chlorella Cream & Chlorella (Chlorophyta) & $20 \%$ CGF & $\begin{array}{l}\text { Skin care: Nourishes and } \\
\text { hydrates the skin }\end{array}$ \\
\hline $\begin{array}{l}\text { Kalia Naturel (Bondy, France) } \\
\text { https:// kalianature.com/fr/, } \\
\text { accessed on } 2 \text { March } 2021\end{array}$ & Protect My Hair & $\begin{array}{l}\text { Arthrospira/Spirulina } \\
\text { (Cyanobacteria) }\end{array}$ & Microalgae powder & $\begin{array}{l}\text { Hair care: strengthens the } \\
\text { hair and accelerates their } \\
\text { growth }\end{array}$ \\
\hline \multirow{3}{*}{$\begin{array}{l}\text { Algenist (Torrance, CA, USA) } \\
\text { https:/ / www.algenist.com/, } \\
\text { accessed on } 2 \text { March } 2021\end{array}$} & $\begin{array}{c}\text { BLUE ALGAE VITAMIN } \\
\text { C }^{\mathrm{TM}} \text { Dark Spot } \\
\text { Correcting Peel }\end{array}$ & $\begin{array}{l}\text { Arthrospira/Spirulina } \\
\text { (Cyanobacteria) }\end{array}$ & Extracted vitamin $C$ & $\begin{array}{c}\text { Skin care: reduces the } \\
\text { appearance of dark spots \& } \\
\text { discolorations }\end{array}$ \\
\hline & $\begin{array}{l}\text { ELEVATE Advanced Lift } \\
\text { Contouring Cream }\end{array}$ & $\begin{array}{l}\text { Dunaliella salina } \\
\text { (Chlorophyta) }\end{array}$ & n.d. & Skin care: anti-aging \\
\hline & $\begin{array}{l}\text { GENIUS Liquid } \\
\text { Collagen }^{\circledR}\end{array}$ & $\begin{array}{c}\text { Parachlorella beijerinckii and } \\
\text { Auxenochlorella protothecoides } \\
\text { (Chlorophyta) }\end{array}$ & $\begin{array}{l}\text { Parachlorella beijerinckii } \\
\text { Exopolysaccharides and } \\
\text { Chlorella protothecoides Oil }\end{array}$ & $\begin{array}{l}\text { Skin care: enhances skin's } \\
\text { bounce and resilience }\end{array}$ \\
\hline $\begin{array}{c}\text { Estee lauder (New York, USA) } \\
\text { https:/ / www.esteelauder.fr, } \\
\text { accessed on } 17 \text { March } 2021\end{array}$ & $\begin{array}{c}\text { Nutritious Micro-Algae, } \\
\text { Pore Purifying Cleansing } \\
\text { Jelly }\end{array}$ & $\begin{array}{c}\text { Chlorella vulgaris } \\
\text { (Chlorophyta) and Arthrospira } \\
\text { platensis (Cyanobacteria) }\end{array}$ & $\begin{array}{l}\text { Chlorella vulgaris extract and } \\
\text { Spirulina platensis powder }\end{array}$ & $\begin{array}{l}\text { Skin care: gel to remove } \\
\text { makeup and impurities. }\end{array}$ \\
\hline \multirow{7}{*}{$\begin{array}{l}\text { Givaudan (Vernier, Switzerland) } \\
\text { https://www.givaudan.com/, } \\
\text { accessed on } 17 \text { March } 2021\end{array}$} & Depollutine & \multirow[t]{2}{*}{$\begin{array}{l}\text { Phaeodactylum tricornutum } \\
\text { (Bacillariophyta) }\end{array}$} & Peptidic extract & $\begin{array}{l}\text { Skin care: Anti-pollution, } \\
\text { anti-ageing }\end{array}$ \\
\hline & Sensityl ${ }^{\mathrm{TM}}$ & & Water extract & Skin care: calm the skin \\
\hline & Costalane & \multirow[t]{2}{*}{$\begin{array}{l}\text { Skeletonema costatum } \\
\text { (Bacillariophyta) }\end{array}$} & $\begin{array}{l}\text { Poly-unsaturated fatty acid } \\
\text { rich in omega-3 }\end{array}$ & $\begin{array}{c}\text { Skin care: restore skin } \\
\text { homeostasis and promotes } \\
\text { epidermal differentiation }\end{array}$ \\
\hline & Grevilline $^{\mathrm{TM}} \mathrm{PF}$ & & Peptidic extract & $\begin{array}{l}\text { Anti-inflammatory, } \\
\text { Anti-redness }\end{array}$ \\
\hline & Hydrintense & $\begin{array}{l}\text { Porphyridium purpureum } \\
\text { (Rhodophyta) }\end{array}$ & Exopolysaccharide & Skin care: hydrates the skin \\
\hline & Mariliance & $\begin{array}{l}\text { Rhodosorus marinus } \\
\text { (Rhodophyta) }\end{array}$ & n.d. & Neurosoother \\
\hline & blue algae life water & $\begin{array}{l}\text { Arthrospira/Spirulina } \\
\text { (Cyanobacteria) }\end{array}$ & $\begin{array}{l}\text { Extract rich in vitamins, } \\
\text { minerals, trace elements, and } \\
\text { essential amino-acid }\end{array}$ & $\begin{array}{l}\text { Skin care: stimulates and } \\
\text { revitalizes the skin }\end{array}$ \\
\hline \multirow{4}{*}{$\begin{array}{l}\text { Microphyt (Baillargues, France) } \\
\text { http:/ / www.microphyt.eu/, } \\
\text { accessed on } 20 \text { March } 2021\end{array}$} & ReinaPhyt & \multirow{2}{*}{$\begin{array}{l}\text { Chlamydomonas reinhardtii } \\
\text { (Chlorophyta) }\end{array}$} & \multirow{2}{*}{ extract rich in carotenoids } & Skin care: protects the skin \\
\hline & $\begin{array}{l}\text { MonaPhytcarotenes rich } \\
\text { extract }\end{array}$ & & & Skin care: rejuvenates the skin \\
\hline & Luteana & $\begin{array}{c}\text { Tisochrysis lutea (Haptophyta, } \\
\text { Coccolithophyceae) }\end{array}$ & $\begin{array}{l}\text { lipidic fractions rich in } \\
\text { xanthophylls }\end{array}$ & $\begin{array}{l}\text { Skin care: soothing effect and } \\
\text { anti-aging }\end{array}$ \\
\hline & Renouvellance & $\begin{array}{l}\text { Porphyridium purpureum } \\
\text { (Rhodophyta) }\end{array}$ & Phycoerythrin and EPS & $\begin{array}{l}\text { Skin care: Anti-aging, } \\
\text { anti-pollution, exposomial } \\
\text { protection, radiance enhancer } \\
\text { and sun care }\end{array}$ \\
\hline $\begin{array}{l}\text { Expanscience (Epernon, France) } \\
\text { with microphyt (Baillargues, } \\
\text { France) https: } \\
\text { / / www.expanscience.com/fr/, } \\
\text { accessed on } 25 \text { March } 2021\end{array}$ & ALGAENIA & $\begin{array}{l}\text { Chlamydomonas acidophila } \\
\text { (Chlorophyta) }\end{array}$ & peptide concentrate & $\begin{array}{l}\text { Skin care: protects sensitive } \\
\text { skin }\end{array}$ \\
\hline
\end{tabular}


Table 7. Cont.

\begin{tabular}{|c|c|c|c|c|}
\hline Industry & Product & Microalgae & Fraction Used & Effect \\
\hline $\begin{array}{c}\text { GREENSEA (Mèze, France) } \\
\text { http://greensea.fr/, accessed on } \\
27 \text { March } 2021\end{array}$ & Silidine $^{\circledR}$ & $\begin{array}{l}\text { Porphyridium purpureum } \\
\text { (Rhodophyta) }\end{array}$ & $\begin{array}{l}\text { mixture of oligosaccharides } \\
\text { and trace elements }\end{array}$ & $\begin{array}{l}\text { Skin care: corrects skin } \\
\text { dysfunctions }\end{array}$ \\
\hline \multirow{3}{*}{$\begin{array}{l}\text { Symrise (Holzminden, Germany) } \\
\text { https:/ / www.symrise.com/, } \\
\text { accessed on } 29 \text { March } 2021\end{array}$} & SymControl & $\begin{array}{l}\text { Tetraselmis suecica } \\
\text { (Chlorophyta) }\end{array}$ & n.d. & $\begin{array}{l}\text { Skin care: reduce sebum } \\
\text { overproduction, soothing the } \\
\text { skin and strengthening the } \\
\text { skin barrier. }\end{array}$ \\
\hline & SymBronze ${ }^{\circledR} 1659$ & \multirow{2}{*}{$\begin{array}{l}\text { Isochrysis Galbana } \\
\text { (Haptophyta, } \\
\text { Coccolithophyceae) }\end{array}$} & n.d. & $\begin{array}{l}\text { Skin care: increases skin } \\
\text { pigmentation and accelerates } \\
\text { the natural tanning process }\end{array}$ \\
\hline & SymHair $^{\circledR}$ Force 1631 & & n.d. & $\begin{array}{c}\text { Hair care: prevents hair loss, } \\
\text { improves volume, and makes } \\
\text { hair stronger, healthier, and } \\
\text { more vital }\end{array}$ \\
\hline \multirow{3}{*}{$\begin{array}{l}\text { algoVita (Tunis, Tunisia) } \\
\text { https://www.algovita.tn/, } \\
\text { accessed on } 19 \text { January } 2021\end{array}$} & $\begin{array}{c}\text { CONFORTING } \\
\text { SOOTHING CREAM }\end{array}$ & $\begin{array}{l}\text { Porphyridium purpureum } \\
\text { (Rhodophyta) }\end{array}$ & n.d. & $\begin{array}{l}\text { Skin care: provides intense } \\
\text { and long-lasting hydration, } \\
\text { soothes, and promotes skin } \\
\text { repair. }\end{array}$ \\
\hline & LIPOFILLER SERUM & $\begin{array}{c}\text { Nannochloropsis } \\
\text { (Eustigmatophyceae) }\end{array}$ & n.d. & Skin care: treat older stains \\
\hline & DEPICLEAR SERUM & $\begin{array}{l}\text { Haematococcus lacustris } \\
\text { (Chlorophyta) }\end{array}$ & astaxanthin & $\begin{array}{l}\text { Skin care: unifies skin } \\
\text { complexion while reducing } \\
\text { spots and imperfections. }\end{array}$ \\
\hline
\end{tabular}

\subsection{Use of Microalgae and Cyanobacteria for Biofuel Applications}

The use of microalgae in recent years for the production of "third-generation" biofuel is increasing as this renewable biosource is not in conflict with critical food production. Indeed, it does not compete with agriculture or at the expense of food, as is the case with first- and second-generation biofuels. In addition, biofuel production from microalgae does not cause deforestation or habitat destruction. These microorganisms are suitable for biofuel production thanks to their high content of lipids, which can reach over $84 \%$ of dry cell weight among some species. Lipids produced by microalgae are converted into biofuels, biogas, dihydrogen $\left(\mathrm{H}_{2}\right)$, and bioelectricity. The term biofuels encompass biodiesel, bioethanol, and biomethane. From microalgae containing $30 \%$ oil by weight of dry biomass, 587,000 L of oil per hectare can be obtained [12]. Additionally, their richness of carbohydrates is convertible to fermentable sugars, making them convenient for bioethanol production [107]. Moreover, the production of biofuel by microalgae has the advantage of reducing greenhouse gas emissions and preserving the environment. It has been reported that, during their growth, a production of $100 \mathrm{~kg}$ of algae consumes $182 \mathrm{~kg}$ of $\mathrm{CO}_{2}$, which has a positive effect on the climate; in addition, some species could use SOx and NOx as a nutrient source $[38,105]$.

The global biofuel algae market is expected to have a CAGR of $8.8 \%$ and to reach USD 10.73 billion by 2025 , with a dominance of their use in transportation to account for over $70 \%$ of the total demand (www.grandviewresearch.com/, accessed on 19 January 2021).

However, until now, there have been many challenges and difficulties of this production, such as the enormous water demand and the necessity of maintaining algae cultivation across all climates. If wastewater is used to produce oil, the barrel of algae oil could cost USD 332, according to the estimation of Lundquist et al. [108]. This price is too high compared to crude oil, which was USD 80 in 2010 as the average closing price and USD 56 in 2021. The proposed solutions are to capitalize the production and develop technologies for larger-scale productions. Some industries use genetically modified microalgae or Cyanobacteria to produce biofuel, as in the case of Algenol, which uses modified Cyanobacteria for ethanol production [109]. European Aeronautic Defence and Space (EADS), the parent company of Airbus, used, in 2010, 100\% derived biofuel microalgae to fly a Diamond DA42NG for 4 days. With the aim of testing and certification, Solazyme (San Francisco, CA, USA) produced over 36,000 L of 100\% algae-derived biofuel destined for the U.S. Navy in 2010. In the next few years, it is awaited that North America will be the largest market, accounting 
for over 30\% (www.grandviewresearch.com/, www.grandviewresearch.com/, accessed on 19 January 2021). In addition to Solazyme, there are many industries producing energy based on algae in the United States, such as Algenol, Blue Marble Production, Sapphire Energy, Culture Biosystems, Genifuels, Seambiotic, Solix Biofuels, and Algae Production Systems, and in other countries, such as Proviron in Belgium (Hemiksem, Belgium).

\section{Conclusions}

Microalgae is a group of eukaryotic photosynthetic microorganisms that thrive in many habitats and present significant taxonomic diversity. They present obvious properties distinguishing them from Cyanobacteria (sometimes called prokaryotic microalgae or bluegreen microalgae). Typically, microalgae are photoautotrophic microorganisms producing biomass with great efficiency using water, solar energy, and $\mathrm{CO}_{2}$, implying biochemical diversity, which becomes the basis for many biotechnological, commercial, and industrial sectors to harness the growing demands of such an unexplored natural resource.

Despite the huge use of microalgal and Cyanobacterial biomass in many industrial applications, as presented in this review, some bioactive compounds from these biomasses still depict an entirely passive role because of the photoproduction, extraction, and purification costs. Moreover, the selection of algal strains after screening from collections or isolation from different environments as well as their cultivation in appropriate culture media always require numerous developments. Thus, the development of novel and adapted extraction and purification methodologies applied to algal biomass might initiate the turning event toward wider industrial utilization. Moreover, the improvement of biomass production in photobioreactors after process intensification could, probably in the future, significantly increase biomass yields by capturing $\mathrm{CO}_{2}$. Indeed, photoproduction in dilute aqueous media using natural or artificial light remain currently inappropriate for large-scale biomass production and low-value applications. Additionally, more work needs to be done to fully utilize the potential of microalgae and Cyanobacteria biomass for their application in large-scale production. Since the key challenges appear to be the high cost of operation, infrastructure, maintenance, mass production, bioproduct accumulation, and extraction, a proposed solution is the cultivation of microalgae in wastewaters, thanks to their ability to assimilate organic and inorganic carbon as well as inorganic nitrogen $(\mathrm{N})$ and phosphorous $(\mathrm{P})$, in order to reduce the cost of cultures.

Author Contributions: I.F. and P.M. conceived and designed the research; R.H. (Rihab Hachicha), F.E., H.B.H., P.D., H.d.B., C.D., G.P., R.H. (Ridha Hachicha) and S.A. analyzed and interpreted the data; writing-review and editing, R.H. (Rihab Hachicha), F.E. and H.B.H. All authors have read and agreed to the published version of the manuscript.

Funding: This work has been funded by the Franco-Tunisian program (PHC UTIQUE-46201NH).

Institutional Review Board Statement: Not applicable.

Informed Consent Statement: Not applicable.

Data Availability Statement: Not applicable.

Conflicts of Interest: The authors declare no conflict of interest.

\section{References}

1. Jacob-Lopes, E.; Maroneze, M.M.; Queiroz, M.I.; Zepka, L.Q. Handbook of Microalgae-Based Processes and Products: Fundamentals and Advances in Energy, Food, Feed, Fertilizer, and Bioactive Compounds; Academic Press: Cambridge, MA, USA, 2020.

2. Gonçalves, A.L.; Rodrigues, C.M.; Pires, J.C.M.; Simões, M. The Effect of Increasing $\mathrm{CO}_{2}$ Concentrations on Its Capture, Biomass Production and Wastewater Bioremediation by Microalgae and Cyanobacteria. Algal Res. 2016, 14, 127-136. [CrossRef]

3. Alvarez, A.L.; Weyers, S.L.; Goemann, H.M.; Peyton, B.M.; Gardner, R.D. Microalgae, Soil and Plants: A Critical Review of Microalgae as Renewable Resources for Agriculture. Algal Res. 2021, 54, 102200. [CrossRef]

4. Abu-Ghosh, S.; Dubinsky, Z.; Verdelho, V.; Iluz, D. Unconventional High-Value Products from Microalgae: A Review. Bioresour. Technol. 2021, 329, 124895. [CrossRef] [PubMed] 
5. Chapman, V.J.; Chapman, D.J. Classification. In The Algae; Chapman, V.J., Chapman, D.J., Eds.; Macmillan Education: London, UK, 1973; pp. 1-12.

6. Palinska, K.A.; Surosz, W. Taxonomy of Cyanobacteria: A Contribution to Consensus Approach. Hydrobiologia 2014, 740, 1-11. [CrossRef]

7. Rockwell, N.C.; Lagarias, J.C.; Bhattacharya, D. Primary Endosymbiosis and the Evolution of Light and Oxygen Sensing in Photosynthetic Eukaryotes. Front. Ecol. Evol. 2014, 2, 66. [CrossRef]

8. Mostafa, S.S.M. Microalgal Biotechnology: Prospects and Applications; IntechOpen: London, UK, 2012.

9. Lauersen, K.J. Eukaryotic Microalgae as Hosts for Light-Driven Heterologous Isoprenoid Production. Planta 2019, $249,155-180$. [CrossRef]

10. Lee, R.E. Phycology; Cambridge University Press: Cambridge, UK, 1989.

11. Pulz, O.; Gross, W. Valuable Products from Biotechnology of Microalgae. Appl. Microbiol. Biotechnol. 2004, 65, 635-648. [CrossRef]

12. Suresh, K.S.; Suresh, P.V.; Kudre, T.G. 4-Prospective Ecofuel Feedstocks for Sustainable Production. In Advances in Eco-Fuels for a Sustainable Environment; Azad, K., Ed.; Woodhead Publishing Series in Energy; Woodhead Publishing: Sawston, UK, 2019; pp. 89-117.

13. Garcia-Pichel, F. Cyanobacteria. In Encyclopedia of Microbiology, 3rd ed.; Schaechter, M., Ed.; Academic Press: Cambridge, MA, USA, 2009; pp. 107-124.

14. Mata, T.M.; Martins, A.A.; Caetano, N.S. Microalgae for Biodiesel Production and Other Applications: A Review. Renew. Sustain. Energy Rev. 2010, 14, 217-232. [CrossRef]

15. De Vargas, C.; Audic, S.; Henry, N.; Decelle, J.; Mahé, F.; Logares, R.; Lara, E.; Berney, C.; Le Bescot, N.; Probert, I.; et al. Ocean Plankton. Eukaryotic Plankton Diversity in the Sunlit Ocean. Science 2015, 348, 1261605. [CrossRef]

16. Sheehan, J.; Dunahay, T.; Benemann, J.; Roessler, P. Look Back at the U.S. Department of Energy's Aquatic Species Program: Biodiesel from Algae; Close-Out Report; National Renewable Energy Lab.: Golden, CO, USA, 1998.

17. Norton, T.A.; Melkonian, M.; Andersen, R.A. Algal Biodiversity. Phycologia 1996, 35, 308-326. [CrossRef]

18. Richmond, A. Handbook of Microalgal Culture: Biotechnology and Applied Phycology; Blackwell Publishing: Hoboken, NJ, USA, 2004.

19. Guiry, M.D. How Many Species of Algae Are There? J. Phycol. 2012, 48, 1057-1063. [CrossRef] [PubMed]

20. Metting, F.B. Biodiversity and Application of Microalgae. J. Ind. Microbiol. 1996, 17, 477-489. [CrossRef]

21. García-Balboa, C.; Baselga-Cervera, B.; García-Sanchez, A.; Igual, J.M.; Lopez-Rodas, V.; Costas, E. Rapid Adaptation of Microalgae to Bodies of Water with Extreme Pollution from Uranium Mining: An Explanation of How Mesophilic Organisms Can Rapidly Colonise Extremely Toxic Environments. Aquat. Toxicol. Amst. Neth. 2013, 144-145, 116-123. [CrossRef] [PubMed]

22. Yong, W.K.; Tan, Y.H.; Sze-Wan, P.; Lim, P.E. Response of Microalgae in a Changing Climate and Environment. Malays. J. Sci. 2016, 35, 167-187. [CrossRef]

23. Suparmaniam, U.; Lam, M.K.; Uemura, Y.; Lim, J.W.; Lee, K.T.; Shuit, S.H. Insights into the Microalgae Cultivation Technology and Harvesting Process for Biofuel Production: A Review. Renew. Sustain. Energy Rev. 2019, 115, 109361. [CrossRef]

24. De Morais, M.G.; da Vaz, B.S.; de Morais, E.G.; Costa, J.A.V. Biologically Active Metabolites Synthesized by Microalgae. BioMed Res. Int. 2015, 2015, 835761. [CrossRef]

25. Dvořák, P.; Casamatta, D.A.; Hašler, P.; Jahodářová, E.; Norwich, A.R.; Poulíčková, A. Diversity of the Cyanobacteria. In Modern Topics in the Phototrophic Prokaryotes: Environmental and Applied Aspects; Hallenbeck, P.C., Ed.; Springer International Publishing: Cham, Switzerland, 2017; pp. 3-46.

26. Thajuddin, N.; Subramanian, G. Cyanobacterial Biodiversity and Potential Applications in Biotechnology. Curr. Sci. 2005, 89, 47-57.

27. Whitton, B.; Potts, M. The Ecology of Cyanobacteria: Their Diversity in Time and Space; Springer: Berlin/Heidelberg, Germany, 2002.

28. Vermaas, W.F. Photosynthesis and Respiration in Cyanobacteria. In eLS; American Cancer Society: Atlanta, GA, USA, 2001.

29. Whitton, B. Diversity, Ecology, and Taxonomy of the Cyanobacteria. Photosynth. Prokaryotes 1992, 1-51. [CrossRef]

30. Vachard, D. Cyanobacteria. In Reference Module in Earth Systems and Environmental Sciences; Elsevier: Amsterdam, The Netherlands, 2019.

31. Stal, L.J.; Moezelaar, R. Fermentation in Cyanobacteria. FEMS Microbiol. Rev. 1997, 21, 179-211. [CrossRef]

32. Andersen, R.A. Diversity of Eukaryotic Algae. Biodivers. Conserv. 1992, 1, 267-292. [CrossRef]

33. Cavalier-Smith, T. Principles of Protein and Lipid Targeting in Secondary Symbiogenesis: Euglenoid, Dinoflagellate, and Sporozoan Plastid Origins and the Eukaryote Family Tree1,2. J. Eukaryot. Microbiol. 1999, 46, 347-366. [CrossRef] [PubMed]

34. Raven, J.A.; Allen, J.F. Genomics and Chloroplast Evolution: What Did Cyanobacteria Do for Plants? Genome Biol. 2003, 4, 209. [CrossRef]

35. Jeffrey, S.W.; Wright, S.W.; Zapata, M. Microalgal Classes and Their Signature Pigments. Phytoplankton Pigment. 2011. [CrossRef]

36. Archibald, J.M. Endosymbiosis and Eukaryotic Cell Evolution. Curr. Biol. 2015, 25, R911-R921. [CrossRef] [PubMed]

37. Baurain, D.; Brinkmann, H.; Petersen, J.; Rodríguez-Ezpeleta, N.; Stechmann, A.; Demoulin, V.; Roger, A.J.; Burger, G.; Lang, B.F.; Philippe, H. Phylogenomic Evidence for Separate Acquisition of Plastids in Cryptophytes, Haptophytes, and Stramenopiles. Mol. Biol. Evol. 2010, 27, 1698-1709. [CrossRef] [PubMed]

38. Person, J. Livre Turquoise-Algues, Filière Du Future; Actes Colloq; Adebiotech: Romainville, France, 2011.

39. Levasseur, W.; Perré, P.; Pozzobon, V. A Review of High Value-Added Molecules Production by Microalgae in Light of the Classification. Biotechnol. Adv. 2020, 41, 107545. [CrossRef] [PubMed] 
40. De Reviers, B. Biologie et Phylogénie des Algues; Belin Editeur: Paris, France, 2002.

41. Groendahl, S.; Kahlert, M.; Fink, P. The Best of Both Worlds: A Combined Approach for Analyzing Microalgal Diversity via Metabarcoding and Morphology-Based Methods. PLoS ONE 2017, 12, e0172808. [CrossRef]

42. Correa, I.; Drews, P.; Botelho, S.; de Souza, M.S.; Tavano, V.M. Deep Learning for Microalgae Classification. In Proceedings of the 2017 16th IEEE International Conference on Machine Learning and Applications (ICMLA), Cancun, Mexico, 18-21 December 2017; pp. 20-25.

43. Heimann, K.; Huerlimann, R. Microalgal Classification: Major Classes and Genera of Commercial Microalgal Species. In Handbook of Marine Microalgae; Kim, S.-K., Ed.; Academic Press: Cambridge, MA, USA, 2015; Chapter 3; pp. $25-41$.

44. Malcata, F.X.; Pinto, I.S.; Guedes, A.C. (Eds.) Marine Macro-and Microalgae: An Overview; CRC Press: Boca Raton, FL, USA, 2018.

45. Fritsch, F.E. The Structure and Reproduction of The Algae, 1st ed.; Cambridge University Press: Cambridge, UK, $1922 ;$ Volume 1.

46. Fritsch, F.E. The Structure and Reproduction of The Algae, 1st ed.; Cambridge University Press: Cambridge, UK, $1922 ;$ Volume 2.

47. Ruggiero, M.A.; Gordon, D.P.; Orrell, T.M.; Bailly, N.; Bourgoin, T.; Brusca, R.C.; Cavalier-Smith, T.; Guiry, M.D.; Kirk, P.M. A Higher Level Classification of All Living Organisms. PLoS ONE 2015, 10, e0119248. [CrossRef]

48. Sialve, B.; Steyer, J.-P. Les microalgues, promesses et défis. Innov. Agron. 2013, 26, 25-39.

49. Rochet, M.; Legendre, L.; Demers, S. Photosynthetic and Pigment Responses of Sea-Ice Microalgae to Changes in Light Intensity and Quality. J. Exp. Mar. Biol. Ecol. 1986, 101, 211-226. [CrossRef]

50. Pazderník, B.M. Light Harvesting Complexes and Chromatic Adaptation of Eustigmatophyte Alga Trachydiscus Minutus. Ph.D. Thesis, Faculty of Science, University of South Bohemia, České Budějovice, Czech Republic, 2015.

51. Dutton, H.J.; Juday, C. Chromatic Adaptation in Relation to Color and Depth Distribution of Freshwater Phytoplankton and Large Aquatic Plants. Ecology 1944, 25, 273-282. [CrossRef]

52. Hentati, F.; Tounsi, L.; Djomdi, D.; Pierre, G.; Delattre, C.; Ursu, A.V.; Fendri, I.; Abdelkafi, S.; Michaud, P. Bioactive Polysaccharides from Seaweeds. Molecules 2020, 25, 3152. [CrossRef] [PubMed]

53. Ben Hlima, H.; Bohli, T.; Kraiem, M.; Ouederni, A.; Mellouli, L.; Michaud, P.; Abdelkafi, S.; Smaoui, S. Combined Effect of Spirulina Platensis and Punica Granatum Peel Extacts: Phytochemical Content and Antiphytophatogenic Activity. Appl. Sci. 2019, 9, 5475. [CrossRef]

54. Elleuch, F.; Hlima, H.B.; Barkallah, M.; Baril, P.; Abdelkafi, S.; Pichon, C.; Fendri, I. Carotenoids Overproduction in Dunaliella Sp.: Transcriptional Changes and New Insights through Lycopene $\beta$ Cyclase Regulation. Appl. Sci. 2019, 9, 5389. [CrossRef]

55. Elleuch, F.; Baril, P.; Barkallah, M.; Perche, F.; Abdelkafi, S.; Fendri, I.; Pichon, C. Deciphering the Biological Activities of Dunaliella Sp. Aqueous Extract from Stressed Conditions on Breast Cancer: From in Vitro to in Vivo Investigations. Int. J. Mol. Sci. 2020, 21, 1719. [CrossRef]

56. Ibañez, E.; Cifuentes, A. Benefits of Using Algae as Natural Sources of Functional Ingredients. J. Sci. Food Agric. 2013, 93, 703-709. [CrossRef]

57. Becker, E.W. Micro-Algae as a Source of Protein. Biotechnol. Adv. 2007, 25, 207-210. [CrossRef]

58. Sousa, I.; Gouveia, L.; Batista, A.P.; Raymundo, A.; Bandarra, N.M. Microalgae in Novel Food Products; Nova Science Publishers: New York, NY, USA, 2008; pp. 75-112.

59. Niccolai, A.; Chini Zittelli, G.; Rodolfi, L.; Biondi, N.; Tredici, M.R. Microalgae of Interest as Food Source: Biochemical Composition and Digestibility. Algal Res. 2019, 42, 101617. [CrossRef]

60. Da Vaz, B.S.; Moreira, J.B.; de Morais, M.G.; Costa, J.A.V. Microalgae as a New Source of Bioactive Compounds in Food Supplements. Curr. Opin. Food Sci. 2016, 7, 73-77. [CrossRef]

61. Kose, A.; Ozen, M.O.; Elibol, M.; Oncel, S.S. Investigation of in vitro Digestibility of Dietary Microalga Chlorella Vulgaris and Cyanobacterium Spirulina Platensis as a Nutritional Supplement. 3 Biotech 2017, 7, 170. [CrossRef]

62. Siqueira, S.F.; Queiroz, M.I.; Jacob-Lopes, L.Q.Z.E. Introductory Chapter: Microalgae Biotechnology-A Brief Introduction. Microalgal Biotechnol. 2018. [CrossRef]

63. Borowitzka, M.A. Microalgae as Sources of Pharmaceuticals and Other Biologically Active Compounds. J. Appl. Phycol. 1995, 7, 3-15. [CrossRef]

64. Pedrós, R.; Moya, I.; Goulas, Y.; Jacquemoud, S. Chlorophyll Fluorescence Emission Spectrum inside a Leaf. Photochem. Photobiol. Sci. 2008, 7, 498-502. [CrossRef] [PubMed]

65. Gaignard, C.; Gargouch, N.; Dubessay, P.; Delattre, C.; Pierre, G.; Laroche, C.; Fendri, I.; Abdelkafi, S.; Michaud, P. New Horizons in Culture and Valorization of Red Microalgae. Biotechnol. Adv. 2019, 37, 193-222. [CrossRef]

66. Vílchez, C.; Forján, E.; Cuaresma, M.; Bédmar, F.; Garbayo, I.; Vega, J.M. Marine Carotenoids: Biological Functions and Commercial Applications. Mar. Drugs 2011, 9, 319-333. [CrossRef] [PubMed]

67. Molino, A.; Rimauro, J.; Casella, P.; Cerbone, A.; Larocca, V.; Chianese, S.; Karatza, D.; Mehariya, S.; Ferraro, A.; Hristoforou, E.; et al. Extraction of Astaxanthin from Microalga Haematococcus Pluvialis in Red Phase by Using Generally Recognized as Safe Solvents and Accelerated Extraction. J. Biotechnol. 2018, 283, 51-61. [CrossRef] [PubMed]

68. Rammuni, M.N.; Ariyadasa, T.U.; Nimarshana, P.H.V.; Attalage, R.A. Comparative Assessment on the Extraction of Carotenoids from Microalgal Sources: Astaxanthin from H. Pluvialis and $\beta$-Carotene from D. Salina. Food Chem. 2019, 277, 128-134. [CrossRef]

69. De Raposo, M.F.J.; de Morais, A.M.M.B.; de Morais, R.M.S.C. Carotenoids from Marine Microalgae: A Valuable Natural Source for the Prevention of Chronic Diseases. Mar. Drugs 2015, 13, 5128-5155. [CrossRef] 
70. Cuellar-Bermudez, S.P.; Aguilar-Hernandez, I.; Cardenas-Chavez, D.L.; Ornelas-Soto, N.; Romero-Ogawa, M.A.; Parra-Saldivar, R. Extraction and Purification of High-Value Metabolites from Microalgae: Essential Lipids, Astaxanthin and Phycobiliproteins. Microb. Biotechnol. 2015, 8, 190-209. [CrossRef]

71. Thomas, J.-C. L'antenne Collectrice d'énergie Lumineuse à Phycobiliprotéines Chez Les Cyanobactéries. Bull. Société Bot. Fr. Actual. Bot. 1989, 136, 31-49. [CrossRef]

72. Hamed, I. The Evolution and Versatility of Microalgal Biotechnology: A Review. Compr. Rev. Food Sci. Food Saf. 2016, 15, 1104-1123. [CrossRef] [PubMed]

73. Dammak, M.; Haase, S.M.; Miladi, R.; Ben Amor, F.; Barkallah, M.; Gosset, D.; Pichon, C.; Huchzermeyer, B.; Fendri, I.; Denis, M.; et al. Enhanced Lipid and Biomass Production by a Newly Isolated and Identified Marine Microalga. Lipids Health Dis. 2016, 15, 209. [CrossRef] [PubMed]

74. Dammak, M.; Hadrich, B.; Barkallah, M.; Hentati, F.; Ben Hlima, H.; Pichon, C.; Denis, M.; Fendri, I.; Michaud, P.; Abdelkafi, S. Modelling Tetraselmis Sp. Growth-Kinetics and Optimizing Bioactive-Compound Production through Environmental Conditions. Bioresour. Technol. 2018, 249, 510-518. [CrossRef] [PubMed]

75. Singh, S.; Kate, B.N.; Banerjee, U.C. Bioactive Compounds from Cyanobacteria and Microalgae: An Overview. Crit. Rev. Biotechnol. 2005, 25, 73-95. [CrossRef]

76. Kumar, J.; Singh, D.; Tyagi, M.B.; Kumar, A. Cyanobacteria: Applications in Biotechnology. In Cyanobacteria; Mishra, A.K., Tiwari, D.N., Rai, A.N., Eds.; Academic Press: Cambridge, MA, USA, 2019; Chapter 16; pp. 327-346.

77. Lau, N.-S.; Matsui, M.; Abdullah, A.A.-A. Cyanobacteria: Photoautotrophic Microbial Factories for the Sustainable Synthesis of Industrial Products. BioMed Res. Int. 2015, 2015, 754934. [CrossRef]

78. Markou, G.; Angelidaki, I.; Georgakakis, D. Microalgal Carbohydrates: An Overview of the Factors Influencing Carbohydrates Production, and of Main Bioconversion Technologies for Production of Biofuels. Appl. Microbiol. Biotechnol. 2012, 96, 631-645. [CrossRef]

79. Mourelle, M.L.; Gómez, C.P.; Legido, J.L. The Potential Use of Marine Microalgae and Cyanobacteria in Cosmetics and Thalassotherapy. Cosmetics 2017, 4, 46. [CrossRef]

80. De Raposo, M.F.J.; de Morais, R.M.S.C.; de Morais, A.M.M.B. Bioactivity and Applications of Sulphated Polysaccharides from Marine Microalgae. Mar. Drugs 2013, 11, 233-252. [CrossRef]

81. Christaki, E.; Florou-Paneri, P.; Bonos, E. Microalgae: A Novel Ingredient in Nutrition. Int. J. Food Sci. Nutr. 2011, 62, 794-799. [CrossRef]

82. Galasso, C.; Gentile, A.; Orefice, I.; Ianora, A.; Bruno, A.; Noonan, D.M.; Sansone, C.; Albini, A.; Brunet, C. Microalgal Derivatives as Potential Nutraceutical and Food Supplements for Human Health: A Focus on Cancer Prevention and Interception. Nutrients 2019, 11, 1226. [CrossRef]

83. Škrovánková, S. Seaweed Vitamins as Nutraceuticals. Adv. Food Nutr. Res. 2011, 64, 357-369. [CrossRef] [PubMed]

84. Brasil, B.; Siqueira, F.; Salum, T.; Zanette, C.; Spier, M. Microalgae and Cyanobacteria as Enzyme Biofactories. Algal Res. 2017, 25, 76-89. [CrossRef]

85. Lu, Y.; Xu, J. Phytohormones in Microalgae: A New Opportunity for Microalgal Biotechnology? Trends Plant Sci. 2015, 20, 273-282. [CrossRef] [PubMed]

86. Bajguz, A. Brassinosteroids in Microalgae: Application for Growth Improvement and Protection Against Abiotic Stresses. In Brassinosteroids: Plant Growth and Development; Hayat, S., Yusuf, M., Bhardwaj, R., Bajguz, A., Eds.; Springer: Berlin/Heidelberg, Germany, 2019; pp. 45-58.

87. Amorim, M.L.; Soares, J.; dos Coimbra, J.S.R.; de Leite, M.O.; Albino, L.F.T.; Martins, M.A. Microalgae Proteins: Production, Separation, Isolation, Quantification, and Application in Food and Feed. Crit. Rev. Food Sci. Nutr. 2020, 61, 1976-2002. [CrossRef]

88. Pruvost, J.; Cornet, J.-F.; Pilon, L. Large-Scale Production of Algal Biomass: Photobioreactors. In Algae Biotechnology: Products and Processes; Bux, F., Chisti, Y., Eds.; Green Energy and Technology Springer: Cham, Switzerland, 2016; pp. 41-66.

89. Costa, J.A.V.; de Morais, M.G. An Open Pond System for Microalgal Cultivation. In Biofuels from Algae; Pandey, A., Lee, D.-J., Chisti, Y., Soccol, C.R., Eds.; Elsevier: Amsterdam, The Netherlands, 2014; Chapter 1; pp. 1-22.

90. Costa, J.A.V.; Freitas, B.C.B.; Santos, T.D.; Mitchell, B.G.; Morais, M.G. Open Pond Systems for Microalgal Culture. In Biofuels from Algae, 2nd ed.; Pandey, A., Chang, J.-S., Soccol, C.R., Lee, D.-J., Chisti, Y., Eds.; Biomass, Biofuels, Biochemicals; Elsevier: Amsterdam, The Netherlands, 2019; Chapter 9; pp. 199-223.

91. Jerney, J.; Spilling, K. Large Scale Cultivation of Microalgae: Open and Closed Systems. In Biofuels from Algae: Methods and Protocols; Spilling, K., Ed.; Methods in Molecular Biology; Springer: New York, NY, USA, 2020; pp. 1-8.

92. Singh, G.; Patidar, S.K. Microalgae Harvesting Techniques: A Review. J. Environ. Manag. 2018, 217, 499-508. [CrossRef]

93. Chacón-Lee, T.L.; González-Mariño, G.E. Microalgae for “Healthy” Foods-Possibilities and Challenges. Compr. Rev. Food Sci. Food Saf. 2010, 9, 655-675. [CrossRef]

94. Mobin, S.; Alam, F. Some Promising Microalgal Species for Commercial Applications: A Review. Energy Procedia 2017, 110, 510-517. [CrossRef]

95. An, B.-K.; Kim, K.-E.; Jeon, J.-Y.; Lee, K.W. Effect of Dried Chlorella Vulgaris and Chlorella Growth Factor on Growth Performance, Meat Qualities and Humoral Immune Responses in Broiler Chickens. SpringerPlus 2016, 5, 718. [CrossRef]

96. Milledge, J.J. Microalgae-Commercial Potential for Fuel, Food and Feed. Food Sci. Amp Technol. 2012, 26, 28-30. 
97. Koutsoumanis, K.; Allende, A.; Alvarez-Ordóñez, A.; Bolton, D.; Bover-Cid, S.; Chemaly, M.; Davies, R.; Cesare, A.D.; Hilbert, F.; Lindqvist, R.; et al. Scientific Opinion on the Update of the List of QPS-Recommended Biological Agents Intentionally Added to Food or Feed as Notified to EFSA (2017-2019). EFSA J. 2020, 18, e05966. [CrossRef]

98. U.S.A. Food \& Drug Administration. Summary of Color Additives for Use in the United States in Foods, Drugs, Cosmetics, and Med-ical Devices. FDA: Silver Spring, MD, USA, 2020.

99. Turck, D.; Castenmiller, J.; Henauw, S.D.; Hirsch-Ernst, K.I.; Kearney, J.; Maciuk, A.; Mangelsdorf, I.; McArdle, H.J.; Naska, A.; Pelaez, C.; et al. Safety of Schizochytrium Sp. Oil as a Novel Food Pursuant to Regulation (EU) 2015/2283. EFSA J. 2020, 118, e06242. [CrossRef]

100. Turck, D.; Castenmiller, J.; de Henauw, S.; Hirsch-Ernst, K.I.; Kearney, J.; Maciuk, A.; Mangelsdorf, I.; McArdle, H.J.; Naska, A.; Pelaez, C.; et al. Safety of Astaxanthin for Its Use as a Novel Food in Food Supplements. EFSA J. 2020, 18, e05993. [CrossRef] [PubMed]

101. Van der Voort, M.P.J.; Vulsteke, E.; de Visser, C.L.M. Macro-Economics of Algae Products: Output WP2A7.02; EnAlgae Swansea University: Swansea, UK, 2015.

102. Baert, P.; Bosteels, T.; Sorgeloos, P. Manual on the Production and Use of Live Food for Aquaculture; Food and Agriculture Organization (FAO): Rome, Italy, 1996; pp. 196-251.

103. Oostlander, P.C.; van Houcke, J.; Wijffels, R.H.; Barbosa, M.J. Microalgae Production Cost in Aquaculture Hatcheries. Aquaculture 2020, 525, 735310. [CrossRef]

104. Rizwan, M.; Mujtaba, G.; Memon, S.A.; Lee, K.; Rashid, N. Exploring the Potential of Microalgae for New Biotechnology Applications and beyond: A Review. Renew. Sustain. Energy Rev. 2018, 92, 394-404. [CrossRef]

105. Rumin, J.; Nicolau, E.; de Junior, R.G.O.; Fuentes-Grünewald, C.; Picot, L. Analysis of Scientific Research Driving Microalgae Market Opportunities in Europe. Mar. Drugs 2020, 18, 264. [CrossRef]

106. Morvan, P.-Y.; Vallee, R. Effects of Chlorella Extract on Skin. Pers. Care 2007, 7, 57-64.

107. Khan, M.I.; Shin, J.H.; Kim, J.D. The Promising Future of Microalgae: Current Status, Challenges, and Optimization of a Sustainable and Renewable Industry for Biofuels, Feed, and Other Products. Microb. Cell Factories 2018, 17, 36. [CrossRef]

108. Lundquist, T.; Woertz, I.; Quinn, N.; Benemann, J. A Realistic Technology and Engineering Assessment of Algae Biofuel Production. Energy 2010, 1, 1-178.

109. Legere, E.; Roessler, P.; Miller, H.; Belicka, L.; Yuan, Y.; Chance, R.; Dalrymple, K.; Porubsky, W.; Coleman, J.; Sweeney, K.; et al. Recovery Act-Integrated Pilot-Scale Biorefinery for Producing Ethanol from Hybrid Algae; Algenol Biotech LLC: Fort Myers, FL, USA, 2017. 